1996

\title{
Mexican and U.S. Library Relations
}

Robert A. Seal

Loyola University Chicago, rseal@luc.edu

Follow this and additional works at: https://ecommons.luc.edu/lib_facpubs

Part of the Library and Information Science Commons

\section{Recommended Citation}

Seal, Robert A. “Mexican and U.S. Library Relations.” Advances in Librarianship 20, no. 1 (1996): 69-121.

This Article is brought to you for free and open access by the Faculty Publications and Other Works by Department at Loyola eCommons. It has been accepted for inclusion in University Libraries: Faculty Publications and Other Works by an authorized administrator of Loyola eCommons. For more information, please contact ecommons@luc.edu.

\section{c) (†) $\ominus$}

This work is licensed under a Creative Commons Attribution-Noncommercial-No Derivative Works 3.0 License. Copyright @ 1996 Academic Press, Inc. 


\title{
Mexican and U.S. Library Relations
}

\author{
Robert A. Seal
}

Texas Christian University

Fort Worth, Texas 76129

\section{Introduction}

\section{A. Overview and Purpose}

For many years, librarians in the United States have interacted with their colleagues abroad. One of the earliest instances of "foreign library relations" was the very first American Library Association conference in Philadelphia in 1876, which attracted a number of international visitors. Since that meeting, American libraries have worked with their counterparts around the globe for a variety of reasons. Contact with Latin America libraries began in earnest after World War I and has continued ever since. Because of the close geographic proximity to and historical and cultural links with Mexico, there has been a natural alliance between the librarians of these two countries. This has been especially true in the border region.

This chapter examines recent library interactions involving the United States and Mexico, providing a review of the literature and commentary on current and potential future cooperative endeavors. However, due to space considerations and a dearth of literature describing early work, the focus is limited to the past 30 years, with only selected references to earlier activity. The potential impact of the North American Free Trade Agreement (NAFTA), recent developments in telecommunications and computer technology, and a rising number of "grass roots" binational conferences and projects all make this a good time to review our relationship, librarywise, with our neighbors to the south.

To place the subject of U.S.-Mexico library relations in context, this chapter begins with a brief overview of Mexican librarianship in Section II. Topics include types of libraries, professional activities, library education and research, the impact of technology, obstacles to library development, and sources of information on Mexican librarianship. Whenever possible, the reader is referred to key works in the literature that provide more detailed information. There are also selected references to the broader topic of U.S.- 
Latin American library relations to provide a framework for a discussion of work with Mexico, as well as to emphasize and give credit to key organizations such as the Organization of American States, the Seminar on the Acquisition of Latin American Library Materials (SALALM), the Library of Congress, and others whose activity in libraries in Latin America ultimately affect our relations with Mexico.

Section III addresses library cooperation within Mexico itself, also to put the relations between our two nations in context. This portion of the chapter covers, among other things, the climate for cooperation, obstacles to collaboration, economic considerations, and specific recent examples of resource sharing in Mexico.

The core of this chapter is Section IV, "U.S.-Mexico Library Interaction," which begins with an overview of U.S. involvement in Latin America before moving to the more specific issue of work with Mexico. Topics presented include historical background, key players, exchanges, conference activities, association interaction, library schools, state-to-state programs, and miscellaneous cooperative projects.

The chapter ends with a look to the future in Section $V$, reviewing the advantages of continued and increased cooperation, obstacles to collaborative work, and the impact of NAFTA. A particular focus is on two key questions: "What can the United States offer to Mexican libraries?" and "What can Mexico provide to American libraries?" Potential future activities to promote and strengthen ties between the United States and Mexico also are presented

\section{B. Scope}

The phrase "library relations" can have a variety of meanings in the context of international activity: one-on-one interactions between librarians, the purchase of foreign imprints, attendance at conferences, the exchange of personnel, interlibrary loan, library school programs, etc. This chapter includes all of these and more; however, the exploits of individual librarians who visit Mexico (and vice versa) to work, lecture, and consult are not discussed at any great length. It should not be construed that the work of individuals is not important, rather that such activity is infrequently documented and there are too many instances to address in any meaningful way.

Instead, the emphasis here is on relations in terms of cooperative projects and programs, learning and resource-sharing activities in which both Mexico and United States benefit from working together. While the goal of international relations is often a concrete thing, e.g., the exchange of publications, information, or personnel, the end result is often intangible, e.g., a better understanding of another culture, language, and a way of doing things.

\section{Research Undertaken}

A brief word is in order regarding the research process for this piece. A thorough review of the U.S. literature revealed almost no books and a relatively small number of articles addressing U.S.-Mexico library relations, and very few pieces addressing Mexican librarianship per se. Articles on U.S.Latin American interactions were more common and often useful. Searching the Mexican literature was even more problematic. There is not much "Mexican library literature" to begin with and it is not widely available in the United States. In the case of both American and Mexican literature, many sources on this topic are very much out of date.

So while there has been a long history of cooperation and other interaction, there is little in print, especially recently, to describe it. In addition to bibliographic research on site in the United States and Mexico City, other means of gathering information were employed, such as personal interviews, conversations at conferences in Mexico, and information from colleagues via e-mail and listservs. The end result is a review of primarily recent examples of U.S.Mexico library relations from the literature of both countries, supplemented by information and opinions from colleagues on both sides of the border.

\section{Mexican Librarianship: A Brief Overview}

\section{A. History}

The first libraries in what is now present-day Mexico consisted of "large collections of hieroglyphs that narrated the artistic, scientific, religious, and war experiences of its inhabitants, as well as their traveling and the prosperity and magnificence of pre-Columbian Mexico" (Fernández de Zamora, 1976, p. 4). These massive archival collections were kept in temples under the supervision of Aztec priests. With the arrival of the Spanish in 1521, these "libraries" were destroyed along with the civilization that had created them (Peñalosa, 1953)

The clergy who came to the New World to convert the indigenous population were instrumental in bringing culture and learning to Mexico. They brought the first printing press in 1544 (Peñalosa, 1953) and established the first library on the North American continent in 1534 (Fernández de Zamora, 1976). From that time up until the early twentieth century, overall library development in Mexico was erratic, often nonexistent, and adversely affected by war and revolution.

There are few books on the history of libraries in Mexico, although several articles provide an overview of the topic. Heliodoro Valle (1923) 
wrote a brief piece on librarianship in Mexico in which he described, among other things, major libraries in Mexico City. More recent and very insightful panoramas were done by Peñalosa (1953) and Fernández de Zamora (1976), the latter an in-depth study with a lengthy bibliography of sources from the Mexican library literature. Fernández de Zamora (1987) also compiled a detailed chronology of twentieth-century library developments in her country.

\section{B. Present Status of Mexico's Libraries}

\section{Public Libraries}

Prior to 1983, public libraries were not well developed in Mexico. In 1921, a Department of Libraries was established by the Secretary of Education, José Vasconselos, who also initiated a literacy program (Fernández de Zamora, 1976). This so-called popular library movement was the first concerted attempt to make library services widely available to the populace. It also concentrated on the training of future librarians (Manrique de Lara, 1935). "Succeeding governments did not support library service," wrote Fernández de Zamora (1976, p. 12) and public libraries went into a period of decline with only occasional interest by and support of the Mexican government.

This downward trend ended in 1983 with the establishment of a new initiative, the Programa Nacional de Bibliotecas Públicas (Magaloni de Bustamante, 1993). As a result of this program, public libraries in Mexico grew from 351 to more than 4000 by 1992 and were located in large cities and small villages in every part of the country. This impressive effort was the result of cooperation among municipal and state governments and the Secretary of Public Education (SEP) (Magaloni, 1993). The resultant National Network of Public Libraries, the "Red Nacional de Bibliotecas Públicas" (Dirección General de Bibliotecas, 1991), is not a network in the sense of a consortia carrying out cooperative activities, although it has resulted in a vastly improved library system for the people of Mexico. Each public library now places an emphasis on children's activities and on becoming an integral part of the community it serves (Magaloni, 1993). Overviews of recent public library activity in Mexico were provided by Morales Campos (1990), Magaloni de Bustamante (1992), and Magaloni (1993).

\section{School Libraries}

Because of long-standing neglect and limited funds, there are precious few school libraries in Mexico, both at the elementary and secondary levels. "Although . . . the usefulness of school libraries as an indispensable aid to teachers and students is understood, these libraries have received the least support on the part of the government and educational authorities" (Fernán- dez de Zamora, 1976, p. 18). In fact, the local public library has taken much of the responsibility for providing library materials to public school children (Magaloni de Bustamante, 1993; Morales Campos, 1990). For example, public libraries in the state of Nuevo Leon serve students in 93 different schools, from kindergarten to college (Quintanilla C., 1989). Private schools, due to requirements by SEP, are in moderately better shape in terms of library service (García Moreno, 1980).

\section{Academic Libraries}

Although initially slow to develop, college and university libraries in Mexico have made significant progress since the mid-1960s through increased government support and by utilizing computer technology. Within the larger universities, there are two types of libraries: one directly supports the educational mission of the institution, serving students and professors, while the other is attached to the university research institutes, serving investigators in specific subject areas (Rodríguez Gallardo, 1977). Academic libraries in Mexico may be placed in three broad categories: public universities, polytechnics, and private schools (Lau, 1993). By the end of the 1980s, there were approximately 900 academic libraries in various stages of development (Morales Campos, 1990), from small and very poor to large, well-funded library systems. Although there is no overall coordination of university libraries, SEP and ANUIES (National Association of Universities and Institutions of Higher Education) are working to improve communication and cooperation among that group (Fernández de Zamora, 1991).

Despite improvements in many sectors, a number of academic libraries still lack the human and financial resources to adequately serve their students and faculty. In particular, libraries in the provinces, i.e., outside of Mexico City, have for years been prone to chronic underfunding (Fernández de Zamora, 1990a). As a result, many are, some for the first time, entering into cooperative agreements with other academic libraries in their regions, utilizing technology to communicate and share resources (Morales Campos, 1990). In an earlier article, Morales Campos (1976) provided a general overview of Mexican academic librarianship along with detailed descriptions of several of the country's university libraries. A look at the finances of academic libraries was given by Tamez Solís (1992).

No discussion of this topic would be complete without mention of the largest and most important university system in the country, the Universidad Nacional Autónoma de México (National Autonomous University of Mexico), best known by its acronym, UNAM. Located on a sprawling campus in the southern part of Mexico City, UNAM has at least 170 libraries supporting teaching and research. Its computer catalog and database, LIBRUNAM, is 
not only utilized by the UNAM community, but by academic institutione and special libraries throughout Mexico (Morales Campos, 1990) and internat tionally (León Saavedra, 1983). Rodríguez Gallardo (1992) provided an over view of the UNAM system and its role in the development of Mexican librarianship in the past two decades.

\section{Special Libraries}

In Mexico, the term "special library" refers to both corporate and government libraries and information centers. The majority of these libraries are located in the Federal District (Mexico City) because that is where the majority of industries and the federal government have their headquarters (Rodriguez Gallardo, 1977). Special libraries grew rapidly in the 1970s in response to the information needs of developing industry and technology (Magaloni de Bustamante, 1993) and therefore were among the earliest users of technology for information retrieval in Mexico. Because they are well funded, special libraries and information centers provide high-quality service and possess some of the finest technical collections in the country. Libraries in private industry and business also pay more competitive salaries and thus attract some of the most qualified library school graduates (Morales Campos, 1976). Those companies that do not have their own libraries may rely on special government-sponsored information centers such as Infotec for their information needs (Morales Campos, 1990). Carrión Rodriguez (1992) provided an overview of special libraries, discussing the challenges of increased demand for technical information and rapid technological advances.

\section{The National Library}

Unlike the United States, Mexico has a separate Library of Congress (Biblioteca del Congreso de la Unión) and National Library (Biblioteca Nacional de México). The former, established in 1936 (Fernández de Zamora, 1976), serves the country's legislators and is a legal depository of Mexican publications. The latter, founded by presidential decree in 1867 (Brown, 1885; Rojas, 1919), is located on the campus of UNAM and is administered by UNAM's Instituto de Investigaciones Bibliográficas (Institute of Bibliographic Research). It shares a building with the National Periodicals Library (Hemeroteca Nacional de México) and also has legal depository privileges. It possesses an important rare books and manuscripts collection rich in historical source material.

With a strong emphasis on the humanities, the two national libraries serve a variety of users (Magaloni de Bustamante, 1993), especially university students due to their location. One of the library's most important responsibilities is the production of the national bibliography, the Bibliografia Mexicano (Carrión Rodrígues, 1981). The terminology "National Library" is perhaps misnomer because it is not a federally funded and administered library like a misnom countries, but rather a unit in the custody of a university (UNAM) that of 1967 (Fernández de Zamora, 1992). As such, it only plays a minor role in developing the country's bibliographic services (Litton and Krzys, 1986).

\section{Professional Activities}

\section{Library Organizations}

Librarians in Mexico belong to a number of professional associations, most notably the Asociación Mexicana de Bibliotecarios, Asociación Civil (Mexican Association of Librarians), founded in 1954. Its two primary goals are professional development of the membership and the promotion of libraries and library service. As of 1992, AMBAC had 520 members (Magaloni de Bustamante, 1993) from a variety of types of libraries, although it is dominated by academic and special librarians. AMBAC has several regional divisions and holds an annual meeting, which alternates between Mexico City and other parts of the country.

An AMBAC affiliate group of academic and research librarians founded in 1967 is ABIESI, the Asociación de Bibliotecarios de Enseñanza Superior y de Investigación (Association of Higher Education and Research Librarians). In addition to addressing the concerns and activities of academic librarians, ABIESI is noted for the publication of an interlibrary loan code and a set of minimum standards for university libraries (Rodríguez Gallardo, 1977).

There are several other professional groups organized along subject lines: ANBAGRO (agricultural librarians), BIBAC (biomedical librarians), and ABIMAG (government librarians). In addition, there is a relatively small body dedicated to the needs of professional librarians, the Colegio Nacional de Bibliotecarios (CNB). Small in numbers because the majority of librarians in Mexico are not trained at the master's level as in the United States, the CNB came into being to elevate and maintain the status, as well as to recognize the qualifications, of the professional staff member. It also has the legal responsibility of advising the Mexican government on library matters (Aranda and Gleaves, 1981). On its 10th anniversary in 1989, the CNB sponsored a national seminar addressing issues of concern to the country's professional librarians (Verdugo Sánchez and Fernández de Zamora, 1990).

\section{Library Conferences}

The earliest national gatherings of librarians took place in 1927 and 1928 in Mexico City (Pan American Union, 1930). The first Jornadas (annual meeting) of AMBAC occurred in 1956 with 323 persons in attendance ("Las Primeras Jornadas," 1957). Since that time, Mexico has seen an increasing number of 
library meetings, in recent years sponsored by AMBAC, ABIESI, SEP, UNAM, and the National Council of Science and Technology (CONACYT), These conferences consist almost entirely of contributed papers or panel discussions. There are few committee meetings and a limited number of exhibitors, quite the opposite of the typical American library conference.

In addition to the annual AMBAC Jornadas, two other regular conferences bear mentioning. The first is the Guadalajara book fair, the Feria Internacional del Libro (FIL), held at the end of November and sponsored by the Universidad de Guadalajara (Hoffert, 1993b). Book fairs are very common and popular in Mexico but this gathering is the largest of its kind, attracting hundreds of publishers from throughout Latin America, Europe, and the United States. It includes an ambitious series of concurrent programs on books, literature, and libraries, the latter attracting participants from the United States and Central and South America.

Immediately preceding the FIL every other year is the Coloquio sobre Automatización de Bibliotecas, held in Colima near the west coast of Mexico. Dealing with library automation, this meeting is sponsored by the Universidad de Colima, a leader in the production of CD-ROM databases. Held in conjunction with a users' group meeting for SIABUC, a library software package widely used in Mexico, this conference showcases the latest developments in and applications of library automation.

\section{Library Education}

The most frequently cited reason for lack of library development in Mexico (indeed in most of Latin America) is a dearth of professionally trained librarians (Rodríguez Gallardo, 1977; Goldman, 1978; Macías-Chapula, 1985; Litton and Krzys, 1986). Although some libraries have formally trained staff, many are supervised by untrained personnel who were asked or "volunteered" to be the librarian. The small number of schools that offer library degrees, both master's and bachelor's, cannot keep up with demand for new professionals (Morales Campos, 1976). As a result, many of the library leaders in the country were trained abroad, mainly in the United States, Great Britain, and Canada, often with the financial support of CONACYT (Goldman, 1978).

The Escuela Nacional de Biblioteconomía y Archivonomía (National School of Librarians and Archivists), ENBA, was founded in 1945 and emphasizes the administrative side of the profession. The program at UNAM focuses on the technical aspects of library science. Other library schools are located in Guadalajara, Nuevo León, San Luis Potosí, and Guanajuato (Magaloni de Bustamante, 1993). The master's program at the Universidad de Guanajuato was initiated by CONACYT to help meet the growing demand for trained professionals (Aranda and Gleaves, 1981).
Continuing education is a major focus in Mexico and, consequently, workshops, seminars, and informal courses are offered on a regular basis to personnel at all levels. Organized informal training programs, as opposed to formal education resulting in a degree, are referred to as "diplomados," interrelated courses focusing on a given thematic area, for example, cataloging, reference work, or library automation. Recommended guidelines for diplomado programs were provided by the Colegio Nacional de Bibliotecarios (Verdugo Sánchez, 1992).

\section{E. Library Science Research}

In contrast with the United States and other nations in which university faculty are both teachers and researchers, in Mexico there are separate library science professors and researchers, although the latter occasionally teach. Most such investigators are associated with UNAM's Centro Universitario de Investigaciones Bibliotecológicas (University Center for Library Science Research). Founded in 1981, CUIB's "main goal is to carry out librarianship research to assist in solving national problems directly related to libraries and information centres in the country, and to provide indirect support to education, research, production, administration and diffusion of culture" (Morales, 1987, p. 173). In addition to conducting research, CUIB sponsors numerous training programs and conferences, works on joint projects with overseas colleagues, and publishes extensively in the field of library science (Morales Campos, 1992).

\section{F. Obstacles to Library Development}

Library progress in Mexico is complicated and hindered by periodic economic crises (Orozco-Tenorio, 1988; Fernández de Zamora, 1988, 1990a, 1991) and a change of government every 6 years. Further, library development and finances are highly centralized in the capital while the rest of the country has very limited resources (meeting with Mexican librarians, February 23, 1995). Nevertheless, steady progress is being made due to work at the local and regional level and through the efforts of individual government agencies such as CONACYT which encourages scientific and technical development and emphasizes the importance of information in a developing technological society. In addition to its role in educating Mexican librarians, CONACYT facilitates access to bibliographic databases and coordinates a union list of serials, among other projects (Goldman, 1978).

Another obstacle to library development is an absence of planning. The country lacks an overall information policy and needs "a national body to control information activities" (Lau, 1993, p. 142). Other national library problems include (1) inadequate bibliographic and authority control, (2) lim- 
ited scholarly research, (3) minimal resource sharing, (4) an insufficient number of trained librarians, (5) the lack of a shared national library vision, and (6) uncoordinated development of library automation (meeting with Mexican librarians, February 23, 1995).

\section{G. Impact of Technology}

Many of these difficulties are being addressed and alleviated to some extent through automation. As in the rest of the world, microcomputers and CD. ROMs have had a significant impact on day-to-day library operations in Mexico (Fernández de Zamora, 1990a), and it was probably the first country in Latin America to have access to online databases (Lau, 1993). Currently, great strides are being made in the production of online and CD-ROM databases led by UNAM, the Universidad de Colima, CONACYT, and $\mathrm{CICH}$, the Science and Humanities Information Center at UNAM. Ainsworth (1994) provided a comprehensive look at Mexican electronic resources whereas Levison and Reynel Iglesias (1993) gave an overview of its online industry. Like their counterparts in the rest of the world, Mexican librarians are increasingly using electronic mail to communicate and foster cooperation in the region (Almada de Ascencio and Pérez de Almada, 1991). Use of the Internet is on the rise, too, utilized for the same reasons as colleagues abroad: communication, discussion of issues, reference work, announcement of meetings, and so on.

\section{H. Sources of Information on Mexican Librarianship}

Perhaps the most expedient way to learn about the state of the library activity and development in a given country is through its professional literature. This process is somewhat problematic for Mexico because although the quality is high, the number and breadth of its library publications are limited. There have been several serial publications over the past half century, but most have since ceased. At present there are two established periodicals that describe professional activity and research: Noticiero de la $A M B A C$, the newsletter of the Mexican Association of Librarians, and Investigación Bibliotecológica (Library Research) published by CUTB at UNAM. The former provides news items on association activities, workshops, lectures, etc., whereas the latter primarily publishes scholarly research articles along with a few news notes regarding activities of CUIB researchers. A new, privately published journal, Byblos, attempts to fill a void in the current library journal literature. Newsletters, especially those published by university libraries, are common but generally not indexed.

The best method of keeping pace with library activity and research in Mexico is through its conference proceedings. The most well-known literature of this type are the proceedings (Memorias) of the annual meeting (Forna- das) of AMBAC. But memorias also result each year from a variety of other library conferences sponsored by government agencies, library organizations, and major universities. Although very useful in taking the pulse of librarianship in Mexico, they are not widely available in the United States.

Apart from conference proceedings, library science monographs are few in number. Of particular note is a recent panorama of Mexican librarianship, La Bibliotecologia en el Mexico Actual y Sus Tendencias (Librarianship in Mexico Today and Its Trends) (Dirección General de Bibliotecas, UNAM, 1992), a comprehensive survey of all fields of library activity. A similar compilation of contributed papers was published by CUIB on the occasion of its 10th anniversary: Edición Conmemorativa del X Aniversario del Centro Universitario de Investigaciones Bibliotecológicas (Morales Campos and Ramírez Leyva, 1992).

\section{Library Cooperation in Mexico}

\section{A. General Overview \\ 1. Obstacles}

Because many of the relationships between the United States and Mexico in the field of librarianship are in fact cooperative in nature, a brief overview of resource sharing within Mexico itself is presented in this section. While collaborative efforts are very common in the United States, they are less common and more limited in scope in Mexico and other developing nations. That does not mean that there has not been interest in library cooperation in Mexico, indeed the opposite is true (Fernández de Zamora, 1988). In fact, the subject of resource sharing has been a common theme of seminars and conferences for some years, beginning with the first Jornadas of AMBAC in 1956. At that meeting, several recommendations were made regarding the need for cooperation among the nation's libraries (Fernández de Zamora, Ansoleaga de López, García Velarde, and Saavedra Fernández, 1977).

Nevertheless, library collaboration has not had tremendous success in Mexico. Projects are more difficult to get started and when they do, they often are doomed to failure at the outset because one of two key ingredients is missing: something to share and a true willingness to do so (Orozco Tenorio, 1992). Further, cooperative efforts in Mexico are often informal and depend too much on one person's goodwill or on personal friendships, neither of which can be the basis for long-term success (Orozco Tenorio, 1992). Fortunately, many cooperative endeavors are now being given more weight by the use of written agreements called "convenios" or "acuerdos."

A number of obstacles to successful library cooperation in Mexico have been noted in the literature and in conversations with colleagues. These 
include, but are not limited to (1) minimal knowledge of library holdings in other locations due to the lack of a national bibliographic network like OCLC (2) scant financial resources exacerbated by periodic economic crises? (3) unevenly developed and distributed collections resulting in many libraries with little to share, especially those outside Mexico City; (4) insufficiently trained numbers of staff to carry out resource sharing; (5) nonstandard computer systems, bibliographic record formats, and Spanish language subject headings, and little or no authority control, all of which hinder sharing and accessing data and limit cooperative cataloging efforts; and (6) the lack of a national resource sharing vision.

In addition to these very real barriers, there are also a number of intangible problems such as apathy and government bureaucracy, problems not unique to Mexico. Garduño (1985) pointed out that cooperation in Mexico is subject to political, technical, and organizational factors as well as "professional jealousies and institutional selfishness which impede joint action" (p. 11). He stated that a lack of planning hinders cooperative ventures, many of which are really intended to primarily benefit the institution which created the plan in the first place (Garduño, 1985).

\section{A Changing Environment}

Despite these obstacles, there have been many successes, especially since the early 1980s. Much of the progress has been due to work by individuals and government agencies such as CONACYT, SEP, and the Consejo Nacional para la Cultura y las Artes, as well as professional organizations such as AMBAC, ABIESI, and CNB (Orozco Tenorio, 1992). Fernández de Zamora et al. (1977) and Carrión (1977) also cited the importance of associations and CONACYT, respectively, in the promotion of resource sharing.

The advent of less expensive, more powerful computer technology in the past decade has contributed to the recent progress in library cooperation in Mexico. Shepard (1984) noted that throughout Latin America the application of automation to library and information services has led to centralized technical processing, a broader acceptance of standards, and an increased number of library networks. The use of fax and the Internet has helped an increasing number of libraries be more "connected" and has contributed to more cooperation, especially interlibrary loan. In addition, successful bina* tional projects like the U.S.-Mexico Interlibrary Loan Project and the Transborder Library Forums (discussed in Sections IV,H1 and IV,D,2,b, respec tively) have demonstrated the possibilities of and have spawned new resource sharing efforts in Mexico. Fernández de Zamora (1991) pointed out that Latin American librarianship in the past was characterized by individualism but now collaboration is seen as a means to work more effectively by sharing limited resources.
Indeed, a new environment favorable to cooperation seems to be emerging in Mexico. This trend is apparent from the Mexican library literature, which includes an increasing number of papers and articles focusing on the need for inclumportance of resource sharing. This is especially true for conference proceedings which present both theoretical papers and descriptions of specific projects (Bernal Flores et al., 1982; "Seminario de Cooperación," 1977; "Segundo seminario de Cooperación," 1983; “Reunión de Trabajo," 1988).

Fernández de Zamora et al. (1977) described several areas in which Mexican libraries could and should work together, whereas Robles Zafra (1983) gave a brief history of library collaboration worldwide and in Mexico. Types of cooperation and the elements necessary for success were reviewed by Ramírez Escárcega (1984); Thomas Giraud and Barberena Blásquez (1986); and Fernández de Zamora (1988). Ladrón de Guevara Cox (1990) made several recommendations for improving cooperation, both among Latin American nations and within Mexico. She emphasized the need for AMBAC to take a central role and for conference programs to include presentations on collaboration.

Much of the existing cooperation takes place among academic institutions, and Orozco Tenorio (1977) provided a theoretical look at shared resources for university libraries. Like many of his colleagues, Orozco Tenorio emphasized the economic necessity for and benefit of sharing collections and other resources.

One of the most useful sources of information on networking in Mexico was done in 1987 under the auspices of the Programa Integral para el Desarrollo de la Educación Superior (Complete Program for the Development of Higher Education). The report provided an overview of networking concepts, and listed and analyzed 11 national, regional, and local library systems, past and present. It also outlined obstacles to systems of shared resources and made several specific recommendations for future action. The document's authors concluded that only with great difficulty can Mexico's academic libraries advance if they work alone and that new resource sharing efforts are to be encouraged to help libraries support the advance of teaching and research (Voutssás, Rodríguez, Ladrón de Guevara, Feria, and González Arteaga, 1989).

\section{B. Examples of Resource Sharing in Mexico}

Fernández de Zamora (1990b) described the cooperative efforts of Mexico City libraries to help colleagues after the September 1985 earthquake. Other similar ad hoc efforts could also be cited. Long-term, ongoing library cooperation in Mexico can be grouped into three major categories: consortia and networks, interlibrary loan, and union lists of serials. The following projects are examples only and should not be construed as the total extent of such activity in Mexico. 


\section{Consortia and Networks}

While a national bibliographic network would be highly desirable for Mexico, cooperation might best be done at first on a regional basis (Enciso Carbajal and Gallardo Gómez, 1984) and indeed there have been several such successful endeavors in cities, states, and regions. One of the most often cited achievements is a network of academic, government, and special libraries in the Northeast known as ARDUSI (Acuerdo Regional de Universidades para el Desarrollo de Sistemas Bibliotecarios), founded with the signing of a formal "acuerdo" in 1984. Sáenz (1983) described the origins and goals of this group located in the states of Nuevo Leon and Coahuila, whereas Arteaga Carlebach (1990) reviewed the network's progress after 4 years, discussing its organization and bases of operation. Among its goals are (1) to exchange information about each other's collections, (2) to undertake projects to establish databases, and (3) to plan new user services. Other such regional consortia have also been created with varying success (Fernández de Zamora, 1988).

There are also consortia established along the lines of type of library. These include the Consejo Nacional para Bibliotecas, CONPAB, the state university librarians group, and RENABIT (Red Nacional Bibliotecaria de los Institutos Tecnológicos), a consortium of technical school libraries. The latter, created in 1987, is divided into nine geographic zones. Arjón Castro (1991) described the workings of zone 3 in the southern part of the country.

An active consortium of 21 biomedical libraries known as RENCIS (Red Nacional de Información y Documentación en Salud) has created union catalogs and a CD-ROM of the full text of more than 19 Mexican medical journals. Established in 1992, the network consists mainly of biomedical libraries at universities, but also includes several which are connected with the federal research institutes. Other RENCIS projects include creating databases of tables of contents of journals and document delivery utilizing Ariel (G. Arteaga, personal communication, November 17, 1995).

An outgrowth of the U.S.-Mexico Interlibrary Loan Project (described in Section IV,H,1) is the Grupo AMIGOS consisting of several academic libraries in the Federal District and environs. Among their collaborative efforts is a union catalog of rare books titled ABIMEX, the Antigua Bibliografia Mexicana, of which a CD-ROM version was expected in late 1995 or early 1996. The group is also working to develop a common data format to be used in sharing catalog records (P. Verdejo, personal communication, September 28, 1995). The members of that group are convinced that resource sharing in Mexico is advancing, although there are challenges and obstacles that must be overcome (meeting with Mexican librarians, February 23, 1995).

\section{Interlibrary Loan}

There has long been interest in interlibrary loan in Mexico with the earliest formal activity occurring in the late 1940s (Fernández de Zamora et al., 1977)
T. de Zubarán (1956), noted that the Benjamin Franklin Library (see Section IV $, \mathrm{B}, 1)$ had been requesting loans from the United States since 1943, the year after its founding. This service was discontinued in 1975 (Pérez Monroy, 1991). Special libraries have engaged in cooperative activities, including interlibrary loan (Fernández de Zamora, 1976), whereas the larger university libraries such as UNAM have been obtaining materials from abroad for quite some time. Lau (1982) rviewed the state of interlibrary loan in Mexico, noting that there is sufficient demand and resources to justify its use. In another paper, he presented a series of recommendations to improve ILL service (Lau, 1983).

Despite the fact that interlibrary loan is the most common form of resource sharing internationally, it is conducted on a very limited basis internally in Mexico. There is no national interlibrary loan code or guidelines, although there is an ILL code for academic libraries developed by ABIESI (see Section II,C,1). The borrowing and lending process itself is hindered by (1) limited bibliographic and location tools; (2) a slow and unreliable postal system; and, in some quarters, (3) an unwillingness to participate (Lau, 1982).

That does not mean that ILL does not take place, because it does, but mainly in small groups or within regional consortia. (Ainsworth (1994) noted that ILL agreements in Mexico are traditionally made "library to library" resulting in many individual "acuerdos." To cite just one example of recent progress, the Library of the Querétaro campus of Monterrey Tech (I'TESM) has developed detailed procedures and formal request forms for carrying out interlibrary loan. It follows the ABIESI code and has entered into a number of agreements with other libraries to exchange materials (A. Belandria, personal communication, February 1995). The ITESM-Querétaro program could be a model for other libraries in Mexico.

Interlibrary loan is gradually on the increase in Mexico as computer technology aids in the location and transmission of materials, as demand by users increase, as a new resource sharing attitude emerges, and as the economic situation in Mexico makes it more attractive, indeed necessary, for libraries to consider resource sharing as a viable means of supplying their patrons with information. Lau (1983), in reviewing the Mexican economic crisis of the early 1980s, recognized that interlibrary loan is a necessity in good times, but even more so in bad.

\section{Union Lists}

Union lists are seen as important in Mexico for making selection and deselection decisions and as a basis for library collaboration (Arista and Yáñez, 1983), and a number of such compilations have been issued since the mid-1970s. In fact, some of the earliest successful efforts at cooperation were union lists of serials. Fernández de Zamora et al. (1977) cited a 1949 union list of medica 
and biology journals ("Catálogo Colectivo de Publicaciones Periódicas en la Ciudad de México, sección de medicina y ciencias biológicas") as the first instance of cooperation in Mexico. In 1968, the first national union list serials was issued; it included 13,035 serial titles in 134 libraries (Fernández de Zamora et al., 1977). CONACY'T took this project over in 1971 and in 1976 issued the second edition as a computer database. The country's largest academic library, the UNAM system, published its first union list in 1976 (Arista and Yáñez, 1983).

Union lists and other collective catalogs remain among the most successful cooperative ventures in Mexico. The most recent developments (and successes) in this area emanate from UNAM and the Universidad de Colima. The former provides online databases and CD-ROMs of its serials, theses, and book collections, all of which are heavily used throughout the country for reference work and resource sharing. The UNAM serials database, SERIUNAM, not only includes the holdings of the very large UNAM system, but of 62 other academic libraries as well. It updates, but does not replace, the most recent edition (1988) of CONACYT's union list cited earlier (Ainsworth, 1994). The Universidad de Colima, mentioned elsewhere as a leader in Mexican library technology, also plays an important role in resource sharing by publishing union catalogs and other bibliographic tools on CD-ROM.

\section{U.S.-Mexico Library Interaction}

\section{A. Background: United States Involvement in Latin America}

\section{Introduction}

As noted earlier, librarians from the United States have long had ties with their counterparts in Mexico, Central America, and South America. Led by visionaries like Marietta Daniels Shepard who espoused the importance of the international dimension of librarianship, they have been involved in a variety of ways with their Latin American colleagues. Indeed, the United States has greatly influenced library development south of its borders in a variety of ways (Litton and Krzys, 1986; Fernández de Zamora, 1991). Latin American librarians have studied in the United States; Library of Congress and Dewey classifications and the Anglo-American Cataloging Rules are commonly used in Latin American libraries; and MARC and various other technological advances have influenced library automation (Fernández de Zamora, 1991). While librarianship in the United States has indeed at de Zamora model imitated by others, Thomas Galvin, the first ALA president to attend an AMBAC conference, warned against the idea that our way is the only way. He also urged stronger ties between Mexican and American librarians (Galvin, 1985).

\section{The United States Information Agency (USIA)}

The USIA, through its library and book programs, has also had a significant impact on library development in Latin America. Known abroad as the United States Information Service (USIS), the agency operated 146 special purpose libraries in 88 countries in 1986 including the Benjamin Franklin Library in Mexico City. Fitz (1986) noted that while its primary function is to provide U.S. imprints and library service to foreign nationals, "the USIA library network functions increasingly as an intermediary between foreign leaders in government, politics, the media, business, and academic life and the wealth of information in American government and private-sector collections, including commercial American databases" (p. 126). Fitz (1986) also stressed the USIA role in supporting visits by foreign and U.S. library specialists for the purpose of international exchange and mutual understanding. Sussman (1973) provided another look at the USIS library program, examining its role within the information dissemination role of the U.S. government. Finally, the USIA libraries have an important role in the achievement of the United States foreign policy objective of influencing public attitudes overseas (White, 1970).

\section{The Organization of American States (OAS)}

One of the greatest influences on the overall development of library services, collections, and education in Latin America has been the Organization of American States, formerly the Pan American Union and the Bureau of American Republics (Wilson and Shepard, 1977). While not a U.S. organization per se, the OAS headquarters is located in Washington, and the United States plays a major role in the formulation and execution of its programs. The history of the OAS Library Development Program, founded in 1956, was provided by Wilson and Shepard (1977) who noted that prior to that time the library interests of the OAS were limited to collecting publications from and about member states for its Columbus Memorial Library.

The OAS Library Development Program was founded in response to the recognition that "access to information and knowledge in printed form is essential for economic and technical progress" (Daniels, 1960). To this end, the primary goals of the OAS program were (1) to improve library education and (2) to create bibliographic tools so that the nations of Latin America could make progress on their own. A variety of activities were undertaken, including training of librarians and bibliographers, creation of 
manuals for library staff, development of standards, and the exchange of publications. In addition to improving library service, a parallel goal of the OAS was to reduce illiteracy by providing sufficient numbers of books and promoting reading (Pan American Union, 1962). Mexico benefited from these programs, especially in the area of library education. The OAS provided four to five scholarships annually to study in the United States (Benson, 1990).

In recent years, the OAS has been instrumental in supporting and promoting library cooperation among and within the countries of Latin America (Benson, 1990). Two programs in particular deserve mention: the OAS and UNESCO projects for centralized cataloging (CATACEN) and machine readable cataloging for Latin America (MARCAL) (Litton and Krzys, 1986). Benson (1990) described numerous collaborative projects supported by the OAS library program, including several in which Mexico has assisted its Latin American colleagues.

Specific OAS-funded programs involving Mexico in recent years have included

1. support for the development of the CUIB's "Infobila" database of library science research in Latin America.

2. support for several CUIB courses in the late 1980s and early 1990s to teach research methods to Latin American library science professors.

3. support for Central American librarians to attend the Guadalajara Book Fair (FIL) to participate in pre- and postconference library science programs as well as the reimbursement of speakers' expenses.

4. support of Mexico's national network of public libraries (S. Benson, personal communication, October 2, 1995).

\section{B. Overview and Brief History of Interaction with Mexico}

Although the United States has long had relations with libraries throughout Latin America, the most frequent, and often most fruitful, interactions have been with Mexico. As will be seen later, many contacts have been personal, through conference attendance and excursions to individual libraries. In terms of resource sharing and library development, the most beneficial interactions have been at the institutional level, carried out by dedicated persons from both sides of the border. The three most important players in initiating and developing library relations with Mexico have been the Benjamin Franklin Library in Mexico City, the Library of Congress, and the American Library Association (ALA). In both countries, however, universities and library organizations such as AMBAC and SALALM have also played key roles, as have international organizations such as the OAS.

\section{The Benjamin Franklin Library}

Possibly the single most influential player in fostering relations between libraries and librarians in the United States and Mexico has been the Benjamin
Franklin Library, founded in 1942 by ALA with the support of the U.S. Office of International Affairs (Thigpen, 1969). The Biblioteca Benjamin Franklin, or the BBF as it is known throughout Mexico, was the first of four Latin American libraries founded in the early 1940s (Sussman, 1973). Presented by the United States as a gift to the Mexican people, "the library promised free circulation of books . . . and aspired through materials and promised free circulation of books .... and aspired through materials and while presenting distinguished American works of all types" (Thigpen, 1969, p. 453). In 1953, the Franklin Library became part of the United States Information Service (USIS).

Pérez Monroy (1991), in her history of the Benjamin Franklin Library, noted that the BBF had many purposes, the most important of which was the provision of books and other cultural materials about the United States. the provisfered traditional library services and, in fact to this day, acts as a public library for the Mexican people. But those were, and are, only part of its mission. Among its many functions are two very important ancillary roles: (1) serving as a center for U.S. cultural activities and (2) maintaining and strengthening relations between libraries in both countries (Pérez Monroy, 1991). With regard to the former, the Franklin Library has hosted numerous art exhibits, conferences, and visting scholars and lecturers, many of whom are librarians or library science educators sponsored by the U.S. government as part of cultural exchange programs.

The Franklin is also the site of frequent meetings of local librarians as well as training workshops sponsored by USIS and area institutions. It plays a central role in an ongoing program of interlibrary loan between Mexico and the United States, a program it helped initiate. Mexican librarians are uniformly supportive and appreciative of the BBF for its role in strengthening US.-Mexico library ties. They particularly benefit from the continuing education programs which bring visiting lecturers and provide training for staff, and they are enthusiastic about the ILL program (meeting with Mexican librarians, February 23, 1995). Finally, the BBF has served as a training ground for many Mexican librarians, a number of whom now occupy key positions in major libraries (Pérez Monroy, 1991). In short, the role of the Franklin Library in U.S.-Mexico relations cannot be overemphasized.

\section{The Library of Congress}

Strictly speaking, the Library of Congress (LC) has as its primary mission the provision of the information needs of the legislative branch of government. It is, of course, also the de facto national library of the United States of America. In this role, LC has originated or influenced several important developments in the field of library science in the United States, particularly in the areas of standards, preservation, and resource sharing. In addition to 
its domestic role, $\mathrm{LC}$ has had a major presence abroad with very active and highly successful international programs. Lorenz et al. (1972) described those activities in some detail: a well-developed foreign acquisitions program, centralized cataloging of foreign research materials, production of machine readable cataloging copy, and much more. The Library of Congress also has had an international focus in the areas of reference service, bibliography, special formats collections (music and maps), copyright, and preservation.

Latin America, including Mexico, has been a major focus of these programs for several decades. The Hispanic Division (formerly Foundation) "serves as a center for the pursuit of studies in Spanish, Portuguese, and Latin American culture," and publishes the Handbook of Latin American Studies, the oldest continuous Latin American bibliography (Lorenz et al., 1972, p. 562). In addition to regular buying trips to Mexico, LC staff are also involved in a variety of cooperative programs. In recent years they have conducted automation workshops, invited Mexican librarians to serve as interns at LC, and assisted with the microfilming of official Mexican documents held by the Library of Congress. Staff at LC were also instrumental in the founding of the Latin American Data Base Interest Group (LADIG), a binational effort to facilitate communication among the producers and users of data files from and about Latin America, a project now based at the Universidad de Colima (H. L. Davis, personal communication, September 15, 1995).

Library of Congress' librarians also regularly visit Mexico and are frequent speakers at conferences there. Likewise, Mexican library professionals often travel to Washington to consult with LC staff. In short, our national library has been actively involved in collaborative efforts with Mexican colleagues on several fronts.

\section{The American Library Association}

The American Library Association has long played an active role in international relations (Sullivan, 1972) and has worked in Latin America for several decades. Around 1920, it created the Committee on Library Co-operation with Hispanic Peoples which made its first report in 1921 at the ALA conference in Swampscott, Massachusetts. The 1923-1924 annual report of the Committee commended member Mrs. Maud Sullivan of the El Paso Public Library for her work with Mexican libraries. The report stated that "Mrs. Sullivan is of the opinion that the American Library Association might render service by aiding libraries of Hispanic-American countries, and especially those of Mexico, in securing a more effective organization" ("Annual Reports," 1924, pp. 233 and 234).

"In May, 1928, Mexican librarians entered into closer relations with their American colleagues when the Mexican government sent a delegation to the annual meeting of the American Library Association in West Baden, Indiana. . . . Though an extensive program of library co-operation with the United States was agreed upon, unfortunately it has borne little fruit . . ." (Peñalosa, 1953). In the early 1930s, due to the Depression, little activity took place. By 1933 the Committee had changed its name to Library Cooperation with Latin America (Brief Board and Committee Reports, 1933) and work tion Foundation for 4 years beginning in 1939. Among its successful efforts were (1) research and publication; (2) exchanges with Latin American librarians; (3) donations of books and periodicals on library topics; (4) arranging exhibits (3) don United States; (5) initiating and strengthening relations with libraries; (6) consulation; (7) direct grants; and more (Shaw, 1947).

The next major appearance of ALA in Mexico was its sponsorship in 1942 of the Benjamin Franklin Library (see Section IV,B,1). In the mid1940 s, the International Relations Office carried out a number of projects 1940 the promotion of translating library literature into Spanish; (2) the distribution of bibliographies such ing Handbook of Latin American Studies; and (3) the administration of as the Handbook of Latin American Studies, and library schools (Shaw, 1947). A report to the ALA Board on international activities cited several interactions with Mexico during the previous five years (Shaw, 1947). These included (1) a grant to the Jalisco State Library in Guadalajara for cataloging, (2) support for the U.S. government's cultura relations program through the Books for Latin America Project, (3) grants for books and equipment for Mexican libraries, and (4) various projects in for books and equipment for Mexican libraries, af the aforementioned were support of the Benjaming from the Rockefeller Foundation.

supported by funds from the Rockefeller Foundation.

Relations between ALA and Mexico continued intermittently until 1990 when the International Relations Committee of ALA created a new subcommittee on U.S.-Mexico libraries. The purpose of this body was to coordinate efforts by individuals and groups in the United States who were already working with Mexican colleagues, as well as to provide an opportunity for new projects and interactions. The subcommittee's mission statement expressed "the need for reciprocal respect for cultural values, greater knowledge, better communication and ready sources of accurate information." Among the issues to be addressed were (1) cooperative resource sharing, (2) identification of and access to research and archival collections, especially those in Mexico, (3) training and continuing
(4) librarian exchanges, (5) binational meetings, (6) funding for projects, (4) librarian exchanges,

During its 4-year existence, the U.S.-Mexico Libraries Subcommittee (1) assisted with the donation of college textbooks to Mexican academic 
libraries; (2) cosponsored binational meetings such as the Transborder Library Forums; (3) developed links with AMBAC; (4) encouraged interlibrary loan; (5) promoted exchanges of librarians; and (6) worked with Reed Publishing, the parent company of R. R. Bowker, to expand the American Library Directory to include Mexican libraries (Seal, 1993). It also cosponsored a meeting with Mexican colleagues at the 1991 Guadalajara Book Fair and drafted a resolution recognizing the 50th anniversary of the Benjamin Franklin Library ("Annual Report," 1992).

The subcommittee continued until the summer of 1994 when it was incorporated into a new Subcommittee on Relations with Libraries in Latin America and the Carribbean as part of a reorganization of the International Relations Committee. The new Latin America and Caribbean Subcommittee continued several programs started by the U.S.-Mexico group, for example, exchanges, and also began to branch out into other areas such as establishing links with related library organizations interested in Latin America.

\section{Interactions Involving Individual Librarians}

The most common, and least documented, form of interaction between the library professions of Mexico and the United States involves individual librarians making visits, doing consulting, lecturing, and even working in the neighboring country. In addition, today there is much ongoing interaction among colleagues via phone, fax, and now electronic mail for the purposes of carrying out research, exchanging ideas and information, coauthoring articles, and so on.

\section{Travel, Training, Research, and Employment}

A frequent and potentially beneficial component of international librarianship involves travel to a foreign country. For years, librarians from the United States have gone to Mexico, and vice versa, for just that purpose. Rivera (1941) noted that there are obvious benefits to such activity between the United States and Latin America, i.e., improved cultural awareness and understanding, the establishment of personal contacts, and, in some cases, the acquisition of technical training. This was echoed by Milam (1944a) who wrote "the importance of increasing the interchange of librarians between the United States and the other American countries cannot be overemphasized (p. 299)."

A number of American librarians have traveled to Mexico and published accounts of their visits. Greer (1919) wrote of a trip to reorganize a women's college library in Puebla. Coleman (1934) described several public libraries she toured on a personal visit to Mexico. On a trip to "increase the general effectiveness of the relations between the libraries of the United States and those of Latin American countries," Milam (1944b, p. 229) visited the Franklin
Library in Mexico City. Cluff (1991) gave an account of a visit to Colima where he and a colleague presented a seminar on current library issues and attended a library automation conference. What does not appear in the literature are accounts of U.S. librarians employed in Mexico and vice versa. This includes work as professional staff, library science professors, teachers, and interns, some short term, others on an indefinite basis.

Mexico has for some time sent its librarians to the United States and other countries to learn more about our methods and to conduct research. The leader in coordinating and promoting such activity for Mexico is CUIB, the library science research institute of UNAM (see Section II,E). One of its principle tasks is to sponsor academic exchanges with other institutions, both internally and outside of Mexico ("Estancias en el CUIB," 1991). This very successful program has supported both short- and long-term visits by library school professors, researchers, and practicing librarians for the purposes of observation, study, and teaching both in Latin America countries and in the United States.

\section{Consultants}

Like individual interactions, the majority of work done by library consultants is not well documented in the literature. Such activity may include an informal visit to help with automation planning or to share expertise on collection building; a government-sponsored fact-finding trip; or a full-scale library review and upgrade. In most cases, the movement of consultants is one way, from the United States to Mexico. Two such examples are presented below.

One of the best-known such consulting activities occurred in the fall of 1966 when Carl White and Paul Bixler visited Mexico with the goal of making recommendations on library development, both to the Mexican government and to the Ford Foundation, the latter desiring better information for making decisions on grants. The consultants paid special attention to "university libraries where opportunities for further development are agreed to be singularly important" (White, 1969, pp. viii-ix). White (1969) and Bixler (1969) gathered voluminous data through extensive research and personal interviews on the current state of Mexican libraries before making their final recommendations.

A more recent example of U.S. consultants in Mexico is the work undertaken by the Academy for Educational Development at the Benémerita Universidad Autónoma de Puebla (BUAP) in 1994-1996. The new administration of this public institution of 66,000 students decided to upgrade and modernize all parts of the university, including the library. Following an initial survey by another firm, the AED team was brought in to finalize plans and to implement, with the help of the library's staff, improvements in reference 
service, the book collection, and automation. Among the enhancements were (1) the installation of the Innovative Interfaces integrated library system; (2) approval plans from Blackwell North America; (3) cataloging on OCLC; and (4) OCLC FirstSearch (A. Mathews, personal communication, August 1995). The BUAP library was the first in Latin America to utilize the FirstSearch databases ("Mexican library first in Latin America," 1995)

\section{Interaction at the Association Level}

\section{Overview}

"Professional associations have an influential and dynamic role in the field of international librarianship and the internationalization of the library profession" wrote Bliss (1995, p. 219), who noted that such activity varies depending on the goals of the groups involved. Indeed, much of the interaction between Mexico and the United States is fostered by and occurs within the framework of professional library organizations. These groups over the years have conducted such work in varying intensities depending on member interest, finances, and other factors. Attendance at and participation in conferences, workshops, and seminars, as well as membership in professional organizations, have all provided a forum for the establishment of links and exchange of ideas with very positive results.

In the early 1920s, the Texas State Library invited the newly created Library Department of Mexico's Education Bureau to attend meetings to organize the Southwestern Library Association. This was apparently not the first time that librarians from the two countries had collaborated because in describing that meeting, Heliodoro Valle (1923) wrote "This is another proof that American and Mexican scholars are doing their utmost to cement the good understanding between both peoples . . ." (p. 265). Just a few years later in 1928, librarians from the United States attended a National Librarians' Congress in Mexico City. Early on, the Library Bureau of Mexico had close relations with ALA "to promote the technical advancement of Mexican libraries," and it adopted with slight modifications the ALA cataloging rules (Pan American Union, 1930).

ALA conferences have long been attended by a number of international librarians, many supported at one time by the Carnegie Corporation and the Rockefeller Foundation (Severance, 1938). Although today Mexican librarians do not participate in large numbers due to limited financial resources, there is usually at least one representative at the major conferences. At the same time, American librarians frequently travel to Mexico to take part in the Guadalajara Book Fair, to participate in the AMBAC Jornadas, and to attend special meetings such as the Latin American Seminar on Official Publications ("Latin American seminar," 1991). American and Mexican delegates alike often make speeches and participate in panel discussions, especially those focusing on binational cooperation.

The Texas Library Association (TLA) also maintains contacts with Mexican colleagues who have on occasion attended TLA conferences. At one such meeting, delegates from both countries explored possible collaborative projects ("Minutes of Meeting," 1992). Before its demise, the Southwestern Library Association had a subcommittee that was actively involved in working with colleagues from Mexico, arranging vists to Mexico for its members, and bringing Mexican librarians to the United States to attend the biannual SWLA conference (Sheldon, 1985). The Public Library Association conference in San Diego in March 1991 included a program on U.S.-Mexico library cooperation sponsored by the U.S.-Mexico Libraries Subcommittee of ALA's International Relations Committee.

AMBAC, which has been invited to participate in various library meetings such as American Library Association and the Transborder Library Forums, in 1992 formed its own Comisión de Relaciones Internacionales de la Asociación (International Relations Commission) to work with American and other international library groups (Comisión de Relaciones Internacionales, 1992). Its first task was to organize a colloquium on Mexico-U.S. cooperation at the 1992 Guadalajara Book Fair.

\section{Binational Meetings}

a. The California Conferences. One of the most productive types of cooperation in recent years has been library meetings jointly sponsored by the United States and Mexico. One such gathering, the First Binational Conference on Libraries in California and Baja California, took place in Tijuana, Baja California, January 13 and 14, 1984. With the theme of public library service, it included round table discussions and several formal presentations by librarians from both countries (Ayala, 1984). This was followed by the Second Binational Conference on Libraries of the Californias, November 11 and 12, 1985, in which the scope was broadened to cooperation between libraries in the United States and Mexico. The use of technology to enhance information sharing, personnel exchanges, and serving border populations were just a few of the topics explored ("Hands across the border," 1986). The goal of this second conference was the improvement of library and information services for the Spanish-speaking populations on both sides of the border (Sheldon, 1985).

b. The Transborder Library Forums. The importance of binational meetings was stressed by Gutiérrez-Witt (1985) who noted that such events open channels of communication and provide an opportunity for the discus- 
sion of common problems. Thanks to the grass-roots efforts of librarians in the states of Arizona and Sonora, linkages between the United States and Mexico were firmly established with the first Transborder Library Forum (Foro Binacional de Bibliotecas). The FORO, as that meeting came to be known, turned out to be the just the beginning of a series of binational conferences at which Mexican and U.S. librarians would meet to discuss mutual problems and work cooperatively to solve them.

The first FORO was held in Río Rico, Arizona, not far from the Mexican border, in February 1991. The focus of the conference was the exchange of information and the establishment of contacts among the librarians of both countries. The conference moved into Mexico in February 1992 to Hermosillo, Sonora, attended by an larger contingent of Mexican librarians, including several invited speakers from Mexico City. The central theme of the conference was NAFTA and its potential impact on libraries (Neugebauer, 1992). Other topics included copyright, the exchange of technical information between the United States and Mexico, and library cooperation.

El Paso, Texas, was the site of the Third Transborder Library Forum in February 1993 with the theme of "Libraries and Education in the Americas." In addition to keynote speeches on the importance of libraries in the educational process, U.S. and Mexican colleagues continued discussions of resource sharing, NAFTA, technology, collection development, and preservation. The February 1994 conference in Monterrey, Nuevo Leon, Mexico, became the Trinational Library Forum as Canadian librarians were invited to explore issues related to NAFTA, information technology, public libraries, the exchange of information, and other topics of interest to librarians throughout North America. Although Canadian librarians are now regularly invited, to date their participation has been limited and the focus is still decidedly on U.S.-Mexico library relations.

The Fifth Trinational Library Forum took place in Mexico City in February 1995 amidst an atmosphere of anxiety and concern due to the most recent economic crisis in that country. Although attendance was down, enthusiasm and interest remained high and lively discussions occurred on a variety of topics. Formal presentations were made on library cooperation, international exchange, copyright, and library education, among others. Tucson, Arizona, was the location of the sixth FORO in February 1996. Titled "Coming Full Circle," it took a retrospective look at the first five Transborder Library Forums. FORO VI's topics included binational cooperation, cross-cultural understanding, information technology, business resources, NAFTA, and library education from an international perspective.

While each of the six conferences included formal keynote speeches, the heart of the meetings were the discussion sessions where, despite occasional language differences, colleagues from North America have not only collabo- rated to achieve common goals but have gained a better understanding of another culture and other ways of providing library service. Each of these meetings was planned and executed totally by volunteers, without any formal organization to support or hinder its work.

The impact and importance of the FOROs in promoting transborder cooperation and improving library service in the region cannot be stressed enough. Hoffert (1993a) presented an overview of the first three FOROs, describing their origin and goals. An updated view of the Trinational Library Forum phenomena was provided by Gregory (1995) who noted that "over its 6-year existence, the FORO has taken giant steps toward becoming a permanent vehicle for international cooperation" (p. 508). Indeed, they are a model for future activity between librarians in Mexico and the United States.

\section{Exchange Programs}

a. Overview. One of the most useful forms of international cooperation is the exchange, i.e., visits to the libraries of other countries to gain work experience, update skills, or obtain a better understanding of methods and philosophy. The word "exchange" is somewhat misleading, however, since it rarely involves a simultaneous, if any, trade of personnel. In addition to or in lieu of observing local practice, the visiting librarian may carry out a project, say the cataloging of an archive, the implementation of an automation program, or training staff in reference work. Although there is not a one-toone exchange of staff, there is a beneficial exchange of ideas and cultural viewpoints benefiting all participants.

b. Library Fellows Program. Over the past four decades, there have been a number of international library exchange programs, both formal and informal. Perhaps the best know such activity today is the Library Fellows Program, funded by the United States Information Agency and administered by ALA. In this program, U.S. specialists spend up to 1 year working in libraries overseas, and since its inception in 1986, 133 librarians have participated (B. Doyle, personal communication, August 16, 1995). The Library Fellows Program is a combination goodwill effort and library consultants program in which U.S. librarians assist colleagues in a variety of special projects. Assignments are broadly based: the 1995-1996 fellows were assigned to Zimbabwe, South Africa, Germany, Switzerland, Burma, and several other nations. Participants are required to submit a final report summarizing their accomplishments and explaining how the experience will help them in future endeavors. Since the program's beginning, two American librarians have worked in Mexico, one in Monterrey and another 
in Puebla, both at private universities. A request for a Library Fellow to work in northern Mexico in 1995-1996 went unfilled due to the lack of a qualified applicant.

In 1993, the program was reversed and a pilot project was initiated by ALA and the USIA to bring international librarians to the United States, The first class of International Library Fellows consisted of 10 librarians from Poland, Kenya, Romania, Laos, Morocco, and five other nations, including Mexico. Designed for midlevel librarians with potential for leadership in the profession in their own countries, the International Library Fellows "work in the U.S. for 3 to 10 months to enhance their understanding of contemporary librarianship as practiced in the United States, develop new areas of expertise and establish contacts that will lead to enduring professional and institutional relationships" ("First International Library Fellows," 1993, p. 6).

c. IRC/IRRT Subcommittee on International Exchanges. In addition to the Library Fellows Programs, ALA members have been involved in international exchanges in other ways. A continuing effort is the International Relations Committee/International Relations Round Table Subcommittee on International Exchanges. Initiated in 1985, the joint IRC/IRRT Subcommittee attempts to facilitate librarian exchanges worldwide by (1) collecting information on librarians and libraries with an interest in study visits and exchange programs; (2) disseminating that information to librarians in the United States and overseas; and (3) promoting professional development and fostering friendly and peaceful relationships with countries around the world. Because of the enormity of this task, the subcommittee picks one area of the world to concentrate on every 2 years. Although Latin America was the official focus of 1994-1996, it will continue to be a vital part of the program on an ongoing basis (L. Covert-Vail, personal communication, November 14, 1995).

In addition to creating a database of potential hosts, the subcommittee's projects have included the creation and maintenance of a Directory of Funding Sources and a Directory of Sponsoring Agencies, now merged into a single resource available both electronically and in print. Two other documents are also being created: "Guidelines for Short-Term Visits to the U.S. by Foreign Librarians" and a "Checklist for Preparing for an International Exchange" (S. Milam, personal communication, April 20, 1995).

d. SALALM Exchange Activities. The Seminar on the Acquisition of Latin American Library Materials has actively supported international exchanges involving Latin American libraries. The SALALM Outreach/ Enlace Committee originated in 1985 as an ad hoc group aimed at (1) promot- ing communication between SALALM and Latin American individuals and institutions concerned with books and information; (2) facilitating participation by this group in SALALM; and (3) promoting exchanges between libraries in Latin America and the United States. The committee became permanent in 1989 and continues with the same purposes (S. Milam, personal communication, April 19, 1995).

Enlace made 31 travel awards to bring Latin American librarians to the United States between 1986 and 1995, including several from Mexico. Supported by SALALM funds, miscellaneous grants, and contributions from book dealers, these awards have made possible conference attendance as well as library visits, work experience, and research. Five Mexican librarians served internships in Texas, California, Arizona, and New Mexico in 1994 thanks to an Enlace proposal funded by the U.S.-Mexico Fund for Culture (Fideicomiso para la Cultura México/USA). In 1995, the ALA/IRC Subcommittee on Relations with Libraries in Latin America and the Caribbean announced its intent to work with SALALM Enlace to cosponsor a future internship project involving Latin American and Caribbean librarians.

e. The Mortenson Center. Another opportunity for Mexican librarians to visit the United States is through the Mortenson Center for International Librarianship located at the University of Illinois at Urbana-Champaign. Founded in 1988 with a gift by Dr. C. Walter Mortenson, a retired chemist and lawyer, the center's purpose is "to foster international tolerance and peace by strengthening ties among the world's research libraries and librarians in an effort to ensure access to knowledge throughout the world." It does this through an international exchange program and an annual distinguished lecture series ("Mortenson Center," 1993). The exchange program, initiated in 1989, aims to increase the skills and knowledge of working professionals through work experience in a major U.S. academic library (Bliss, 1995).

f. Texas Library Association Exchange Program. A small but successful program of U.S.-Mexico library exchanges was initiated in 1994 by the Texas-Mexico Relations Subcommittee of the College \& University Library Division of the Texas Library Association. This effort brought two librarians from Mexico City to visit Texas libraries in the summer of 1994 and three more from other parts of Mexico to Texas in 1995. The exchanges are short in duration, between 1 and 2 weeks, but very beneficial: participants visited several libraries and attended workshops. Future plans involve sending American librarians to Mexico (C. Felsted, personal communications, 1994-1995). 


\section{E. Acquisition of Library Materials}

\section{Overview}

An activity that has long afforded an opportunity for meaningful contact among library colleagues in Mexico and the United States has been the acquisition and bibliography of books, periodicals, documents, and other materials from Latin America. Because this topic is covered so well elsewhere in the literature, only brief mention is made here of (1) national cooperative U.S. programs for Latin American acquisitions including Mexico, and (2) SALALM, a group that has been extremely active in this field and that has fostered many relationships, cooperative and otherwise, among U.S. and Mexican librarians.

The acquisition of Latin American library materials has always been problematic, even for librarians in Latin America. Shepard (1968) summarized very well these difficulties when she wrote "the principal problem in the acquisition process has been the bibliographic one-finding out what is being or has been published in Latin America and determining which are the most important of these works . . ." (p. 705). She pointed out that cooperative programs are required to obtain materials from "developing countries whose booktrade is also underdeveloped” (Shepard, 1968, p. 703).

\section{Formal Cooperative Acquisition Programs}

For years, librarians, government, and professional associations in the United States have been working together to acquire materials from developing countries. An excellent overview of early cooperative acquisitions efforts for Latin America can be found in the introduction to the conference proceedings of the first SALALM meeting (Hixson, 1956). The Farmington Plan, established by former Librarian of Congress Archibald MacLeish in 1942, was the largest acquisitions program ever implemented. Although its original focus was collecting publications from Europe, it added Mexico from 1948, and three other Latin American countries soon after. By the early 1960s it was a worldwide effort (Savary, 1975).

At the urging of the members of SALALM, the Farmington Plan was extended full-scale to Latin America, resulting in 1960 in the birth of LACAP, the Latin American Cooperative Acquisitions Program. Unlike Farmington, it was a commerical venture, sponsored by an international book company, Stechert-Hafner, in cooperation with three research libraries. New York Public, the University of Texas, and the Library of Congress. For the first time, books were brought to the United States on a regular basis and in large numbers from nearly every Latin American country. Dozens of collections were enriched and the cost and logistical problems of acquiring such items were significantly reduced. Savary (1975), who provided a detailed and useful history of LACAP, called it "a milestone in library cooperation." For a variety of reasons, however, including rising costs, declining sales, and changes inherent in the Latin American book trade, the program was suspended at the end of 1972 .

\section{Seminar on the Acquisition of Latin American \\ Library Materials}

Before, during, and since LACAP, SALALM has played a key role in helping U.S. libraries carry out the sometimes difficult tasks of the bibliography, acquisition, and cataloging of library materials from North, Central, and South America, and from the Caribbean. The first Seminar on the Acquisition of Latin American Library Materials was held in Florida in June 1956, sponsored by the University of Florida Libraries and the Columbus Memorial Library of the Pan American Union (later the Organization of American States). That gathering of librarians, bibliographers, scholars, book dealers, and others was seen as "the latest link in the chain of cooperative efforts to resolve mutual acquisitions problems" (Hixson, 1956, p. iv).

SALALM eventually evolved into an independent organization separate from OAS with its headquarters rotating among several different universities with major Latin American collections. The Secretariat currently resides at the University of Texas at Austin. Savary (1975) provided a brief history of SALALM's first two decades, describing its role in cooperative acquisitions ventures, especially the founding and operation of LACAP. During those 20 years, the organization saw many accomplishments which benefited libraries in the United States and throughout Latin America. Among these achievements were several pertaining to Mexico: "the rebirth of a current Mexican bibliography; . . . the publication of the Directorio de publicaciones periódicas mexicanas . . .; the improvement of bibliographic lists in a number of trade bibliographics in Mexico . . ." (Wilson and Shepard, 1977, p. 30). The past two decades have seen a number of other bibliographic works from SALALM focusing on Mexico. The organization also presents an annual prize for the best reference book or bibliography on Latin American studies, the José Toribio Medina award, and it plays a major role in the production of HAPI, the Hispanic American Periodicals Index (S. Milam, personal communication, November 14, 1995). Mexican librarians volunteer their time to assist with HAPI, indexing all issues of several journals each year (B. Valk, personal communication, May 10, 1995).

SALALM continues to hold annual conferences to explore issues related to Latin American bibliography and librarianship. The resulting working papers, in addition to providing a historical record of the organization's 
programs, are an invaluable resource for Latin American librarians, scholars, and other specialists. Its support of exchanges through the Enlace program, mentioned earlier, is just another example of its many cooperative activities and the scope of its influence.

\section{Other Programs}

Apart from the formal programs like LACAP and the activity of professional associations such as SALALM there are, of course, many examples of individual libraries and acquisitions librarians working in Mexico and other Latin American nations. These include the Library of Congress as well as university libraries with significant Latin American collections, such as the Benson at the University of Texas, Austin. Their activities range from buying trips to the exchange of materials to the creation of bibliographies, and much more. Latin Americanists are also concerned with and involved in matters of preservation (Hazen, 1995) and in helping Latin American librarians, including those from Mexico, to more easily acquire U.S. publications.

\section{F. U.S. Library Education and Mexican Librarianship}

\section{Overview}

One way in which the United States has affected library development in Mexico and other parts of Latin America is through its formal graduate program of library and information science. Many Mexican librarians have been trained in our library schools, with the support of their government, ALA, and international organizations such as the OAS. As noted earlier, the Benjamin Franklin Library has also had a great deal of influence because many Mexican professionals got their start there and often went on to study library science in the United States.

Morales Campos (1990) noted that the United States has also influenced Mexican library education, and thus its librarianship, primarily in its technical aspects, i.e., the organization of collections and classification schemes, and by its emphasis on reference and children's services. Other countries such as Great Britain and France have also been factors in library development in Mexico. Despite foreign influence, Mexico must ultimately have its own identity in terms of how its libraries are organized and operated. Indeed, this appears to be happening with the emergence of a "bibliotecología mexicana" in the 1980s after decades of accumulated effort and development (Morales Campos, 1990). Morales Campos (1990), in an insightful paper on the Mexican library system, concluded that the combination of external influence and internal developments has resulted in a number of advances in the field and sustained growth that will soon achieve a level of excellence.
With the help of a number of foundations, ALA formerly provided fellowships for Latin Americans to study in our library schools and for American students to survey and study Latin American libraries (Severance, 1938). The OAS has long had as goals to (1) assist in the training of library professionals and (2) train library school professors in Latin America. In the past, the OAS also provided a small number of graduate fellowships to study in the United States and sponsored a variety of courses at the regional and national level "ranging from orientation courses to specialized graduate-level studies" (Wilson and Shepard, 1977). All these programs have benefited librarians from Mexico.

\section{Recent U.S. Library School Activity}

Mexican librarians have studied at a number of U.S. library schools over the past half-century, most notably the University of Texas and the University of Denver, both of which have had special programs for Latin American students. One of the most successful recent programs of American library education aimed at Mexico was that offered in the early 1990s by the School of Library and Information Science of the University of Wisconsin, Milwaukee, for the head librarians of the 26 campuses of the Instituto Tecnologico $y$ de Estudios Superiores de Monterrey (ITESM), the largest private university system in Mexico. At the request of the ITESM administration, the 2-year program had a particular emphasis on library administration and technology. Classes were given in Milwaukee in the summers and in Monterrey in the fall and winter semesters with UWM faculty traveling to Mexico to teach. An intensive English program was offered for those who needed to improve their language skills. Students and faculty kept in touch by mail, phone, email, and fax, and ultimately, 21 members of the class graduated in 1993 with their MLIS degrees. A second program for another group of ITESM librarians had to be postponed due to the 1995 economic downturn (M. Aman, personal communication, August 14, 1995). The success of the UWM-ITESM program demonstrated the possibilities of cooperative library education between the United States and Mexico.

The University of Arizona offers a Masters of Arts degree with an emphasis in Library Science through its distance education program, serving students all over the United States "through virtual and established regional sites." Beginning in the summer of 1995 , the School of Library Science initiated a partnership with the Universidad de las Americas in Puebla to offer the program's courses to librarians in Mexico and throughout Latin America. Students view videotapes of class lectures and receive assignments via the Internet. Future plans include the exchange of faculty and students between University of Arizona and UDLA (C. D. Hurt, personal communication, October 24, 1995). 
Interaction between library schools has also occurred on a less formal basis with the exchange of faculty for both long and short visits. A recent example is an interchange involving the University of North Texas School of Library and Information Sciences and the Escuela Nacional de Biblioteconomía y Archivonomía (National School of Library and Archival Science), ENBA, which took place in 1994. Following a visit to Denton, Texas by the Dean of ENBA, a delegation from the UNT SLIS was invited to Mexico City to participate in a symposium on the "Education of the Librarian of the Future." Several presentations were made by the faculty and doctoral students at the conference ("SLIS Faculty and Students," 1995).

\section{G. Border Relations}

\section{Overview}

The most frequent and intensive interaction between libraries in the United States and Mexico occurs, not surprisingly, in the region encompassing the international border between our two nations. This area, as Gutiérrez-Witt (1985) so aptly pointed out, is a special place with its own history, people, and culture, even though it is arbitrarily divided into two political entities. The border region, she wrote, is neither an American nor Mexican culture but rather a combination of the influences of both peoples and libraries in that region must take this into account when building collections and planning services. The following examples of transborder library cooperation illustrate a strong willingness to work together to achieve common goals despite disparities in resources (collections and personnel) and differing needs and expectations of local users.

\section{Arizona-Sonora Cooperation}

The most prominent example of two bordering states successfully cooperating in the library sphere is that of Arizona and Sonora, an overview of which was provided by Milam and Salas (1990). Collaborative activities have included (1) the exchange of state publications, (2) gifts of scientific and technical books to Mexico, (3) jointly sponsored conferences such as the first Transborder Library Forum, and (4) participation on binational commissions. The original impetus for these successful endeavors was an invitation to Sonoran librarians to attend the 1989 Arizona Library Association (AzLA) conference in Tucson. A direct result of that meeting was the creation of the Asociación Bibliotecaria de Sonora, A.C. (the Sonoran Library Association), the first such group of its kind in that Mexican state (Baldwin, 1991).

Since that time, much of the Arizona-Sonora collaboration has been initiated by AzLA's International Librarianship Round Table (ILRT), which has a standing committee, the Arizona/Mexico Area Committee (AMAC), that coordinates several cooperative ventures. These have involved the exchange of personnel, a reciprocal state document exchange agreement, interlibrary loan, and more (Baldwin, 1991). The AzLA ILRT also collaborated with the Arizona Chapter of the Special Libraries Association to sponsor an International Special Librarians Day in April 1994. That program provided a forum for the exchange of information, planning of cooperative ventures, and further strengthening of ties among librarians (C. Elliott, personal communication, May 16, 1995). The Arizona-Sonora relationship, in all its manifestations, is a model for other border states to emulate.

\section{Collaboration between the Californias}

There has also been an ongoing relationship between California and Baja California, although that interaction might more aptly be described as a San Diego-Tijuana connection because of the close ties between librarians in those two cities. The San Diego Chapter of Special Libraries Association, like its counterpart in Arizona, has also sponsored an International Librarians Day, which involved meetings with Mexican colleagues. LIBROS, the San Diego chapter of REFORMA, invited librarians from Baja California to the California Library Association meeting in 1990 (M. MacPhail, personal communication, May 24, 1995). The California State Library has supported a number of binational meetings with Mexico and has participated in a working group on interlibrary connections among Pacific nations (Ruby, 1985).

\section{Texas-Mexico Interaction}

Public and college libraries located on the border frequently find themselves serving patrons from both countries. Quintanilla C. (1989) described the use of the Piedras Negras (Mexico) public library by Texas citizens, while Garmon (1990) noted that Texas Southmost College in Brownsville routinely serves both U.S. and Mexican patrons. Indeed, public and college libraries from San Diego to the Gulf of Mexico have long welcomed users from both sides of the border. In-house reading and reference help are the most common services offered; loans are less common.

A strong university library connection has developed in the El PasoCiudad Juárez metropolitan area involving the University of Texas at El Paso and the El Paso Community College working in tandem with the Universidad Autónoma de Ciudad Juárez, the Instituto Tecnológico de Ciudad Juárez, and the Instituto Tecnológico y de Estudios Superiores de Monterrey, Ciudad Juárez campus. UTEP has been particularly active, signing several "convenios" to work with Mexican libraries. Under these agreements, students from the Ciudad Juárez schools may use the UTEP Library, borrow books, and 
obtain database searches (Seal, 1992b). Librarians from Ciudad Juárez also participated in the planning of FORO III. The UTEP Library was involved in the project to microfilm Mexican archival records (see Section IV,H,4) along with other Texas libraries (Seal, 1989).

\section{H. Other Forms of Cooperation}

\section{Interlibrary Loan}

As noted earlier in Section III,B,2, Mexico has for some years conducted foreign interlibrary loan, most notably through the Benjamin Franklin Library. The national university, UNAM, treats international requests for photocopies as "document delivery" and therefore changes for such service (E. R. Hernández, personal communication, March 29, 1995). For the most part, Mexican universities carry out some foreign interlibrary loan as the need arises. Informal agreements, such as the one between the Instituto Tecnológico de Chihuahua (IT deC) and the University of Texas at El Paso (UTEP), are sometimes utilized. In this case, a Mexican librarian searches the UTEP catalog via the Internet and faxes requests to their interlibrary loan office (Kahl, 1993). He then travels 250 miles from Chihuahua City to El Paso to pick up the materials that he also personally returns. A similar arrangement involves the ITdeC and the University of New Mexico (D. Warren, personal communication, May 9, 1995).

An exception to the normally infrequent ILL activity between the United States and Mexico is a highly successful formal program of interlending established in 1989 involving academic libraries in Mexico City and the southwestern United States (Seal, 1990b, 1991; Kahl, 1993; Morales Campos, 1994). The so-called U.S.-Mexico Interlibrary Loan Project is a joint effort of the Benjamin Franklin Library (USIS), the University of Texas at El Paso, and the Colegio de México. Requests from Mexico are directed to UTEP, which uses the OCLC ILL system to locate and request items from 1 of 27 AMIGOS member libraries or 2 non-AMIGOS libraries. The U.S. requests are directed to the Colegio de México, which uses various bibliographic tools and the telephone to locate the item in question among the ten participating Mexico City libraries and, more recently, the main campus of Monterrey Tech (ITESM). For the first 5 years of the project, this work was carried out by the Instituto Tecnológico Autónomo de México (ITAM).

In the planning stages, a perceived obstacle to the success of this project, now an ongoing service, was the unreliability of the Mexican postal system, which discourages the internal and external interlibrary loan of books and microforms. This was overcome by utilizing the U.S. Embassy courier, which makes regular deliveries between Mexico City and Laredo, Texas. By the end of FY1994-1995, 7439 requests from Mexico had been filled by the participating U.S. libraries. While no firm figures are available for U.S. requests filled by Mexico, the number is only a fraction of the traffic from Mexico to the United States. Numbers are less important, however, than the accessibility to certain Mexican publications that are not available in the United States, e.g., theses and dissertations, statistical data, government publications, and monographs. Scholars in both countries have benefited from this model program, which received the "Project of the Year" award for 1991 from the Texas Library Association (Kahl, 1993). The project "met its original goals of facilitating the exchange of scholarly information; promoting and enhancing scholarly research; and improving ties between the library and research communities in our two countries" (Seal, 1990b, p. 12).

\section{Book Donation Programs}

Worldwide, book donation programs are a very common form of library assistance and cooperation, undertaken with varying degrees of success (Bliss, 1995). Although such gifts can be very beneficial, there are associated risks and problems that cannot be ignored. Without careful planning and adequate support on the receiving end, "books that are either not needed or dated are sent at great financial cost" (Bliss, 1995). Bixler (1969) discussed the pros and cons of book donation programs in the context of foundation support for Latin American libraries in general and Mexican libraries in particular. Bayardo Gómez (1985) listed criteria for donation and emphasized the need for good communication to ensure that materials of interest sent will be to the receiving parties.

U.S. border libraries are in an excellent position to assist Mexican colleagues by donating duplicates and other unneeded volumes. For example, in the late 1980s and early 1990s the library of the University of Texas at El Paso collected large numbers of textbooks, duplicate periodicals, and unwanted gift books to present to academic libraries in their sister city of Ciudad Juárez. The greatest problem encountered in that program, and similar efforts, was simply getting the materials across the border through Mexican customs.

One of the more recent and ambitious book donation efforts involving the United States and Mexico was sponsored by the Mexican Project Center in Sedona, Arizona. From 1988 to 1990 , more than 50,000 donated technical works were sent by the center to many of the 34 state universities in Mexico. Another several thousand volumes were shipped to several of the 60 technical colleges in 1991-1992. The books were donated by the Nebraska Book Company and the Follett Book Company and transported to the border by Pet Foods and Wyatt Cafeterias. After resolving the difficulties of moving the materials across the border, the books were shipped to various locations in Mexico, with transportation paid by the Mexican government. A highly 
successful program carried out with the assistance of Mexican librarians, this project resulted in several donations to university libraries in desperate need of scientific and technical books (R. Forney, personal communication, August 23, 1995).

\section{Government-Sponsored Collaboration}

In addition to the work described in Section IV,A,2, the U.S. Information Agency has fostered U.S.-Mexico cooperation by periodically bringing together representatives from the two countries to discuss topics of mutual interest. One such program is the Mexican/American Commission on Cultural Cooperation, initiated in 1948 and involving officials of the USIA and the Mexican Foreign Ministry. In 1990, the commission, which meets every 3 years, included for the first time, representatives from private organizations and other government agencies in five areas: libraries, publishing, museums, U.S. studies, and the performing arts.

The U.S. library delegation included six professionals representing universities, ALA, and the Library of Congress, while the Mexican group consisted of six librarians from government, public, and academic libraries. Meeting June 6-7, 1990, the Library Working Group recommended cooperative programs in three areas: human resources, materials resources, and library information services. Specific ideas included (1). the exchange of personnel and training programs; (2) closer ties between professional organizations; (3) increasing scholarships for Mexicans to study in the United States; (4) compiling information on Mexican databases; (5) expanding access to government publications; (6) increasing cooperation between the Library of Congress and the National Library of Mexico; and (7) promoting and expanding existing interlibrary loan efforts ("Mexican, American librarians, 1990). The U.S./Mexican Commission on Cultural Cooperation adopted the Working Group's recommendations in Washington in August 1990. One of the direct outcomes of the binational meetings was the creation by ALA of the U.S.-Mexico Libraries Subcommittee of the International Relations Committee (see Section IV,B,3).

\section{Microfilming Projects}

Two separate efforts to preserve Mexican archival records are yet another example of U.S.-Mexico collaboration. The first, the Texas Consortium to Microfilm Mexican Archival Resources, was founded in 1969 and involved 15 academic libraries and the Texas State Library. Their objective was to film for preservation and research purposes as many Mexican archival collections as possible: national, state, city, and church records. Each of the Texas institu- tions involved chose a geographic area of Mexico and was responsible for carrying out the work in that region. The resulting microfilm was sent to the Texas institution's library with a copy being given to Mexican authorities. This project was the outgrowth of the 1967 International Conference on Mexico on Microfilm, convened to plan for a national consortium to cooperatively film Mexican archives. The Texas project was not seen as a competitor to the national group but rather a complement to it and the work of other groups (Kinney, 1971).

A second project was the Latin American Microform Project (LAMP) initiated in 1975 by 16 U.S. research libraries. Following similar programs that had preceded it, LAMP had two basic premises: first, to make more accessible to scholars important research materials heretofore unavailable except through foreign travel; and second, to preserve disintegrating or poorly stored materials. The LAMP project, initiated by SALALM, is administered through the Center for Research Libraries, which had handled similar projects for other parts of the globe. The project includes filming of newspapers, periodicals, and archical collections held in the United States as well as collections in Latin America. The first decade saw a focus on Mexico and Brazil and, by 1985, the number of participating libraries had increased to 29. The resulting microfilm is held by CRL where it is available for use by the membership (Deal, 1987). While both microfilming projects could be perceived as primarily U.S. ventures, both in fact relied heavily upon the good graces and assistance of archivists and librarians in Mexico and, in the case of LAMP, several other Latin American countries.

\section{U.S. Bibliographic Utilities}

In 1975, the AMIGOS Bibliographic Council began exploring the possibilities of cooperation with Mexican libraries. At that time, AMIGOS had as a major focus the brokering of OCLC cataloging services and it made several presentations in Mexico and elsewhere in an effort to bring shared cataloging to Latin America. However, low hit rates, insufficient numbers of Spanish records, and high costs initially discouraged the widespread adoption of OCLC in Mexico. Quijano Solís (1982) noted that the OCLC system was too costly and inappropriate for Mexican libraries at that time. Nevertheless, UNAM (1982-1983) and the Universidad Iberoamericana (1980-1983) became AMIGOS members for a short time in the early 1980s, committing to use the OCLC Online Union Catalog as their cataloging source. Both were forced to discontinue service due to the financial crisis of the early 1980s.

Because of the costs and time involved in marketing and the inability of Mexican libraries to pay for cataloging and other network services, AMIGOS notified OCLC on March 5, 1992, that it would no longer serve libraries in 
Latin America (P. Mooney, personal communication, November 14, 1995) In 1995, OCLC began marketing its products and services in Mexico and other parts of Latin America as part of its expanding international programs. As a result, a number of Mexican libraries began conducting trials with or purchased FirstSearch. There was a great deal of interest in FirstSearch, WorldCat, and other reference products such as CD-ROMs and electronic journals, none of which require OCLC membership (N. Cop, personal communication, November 7, 1995).

In 1995, the Research Libraries Group (RLG) announced a joint venture with the Centro de Tecnología Electrónica e Informática (CETEI), a nonprofit company based in Mexico City, to provide RLG products to Mexican academic libraries. Under the program, a pilot group of 10 libraries were to have access to the RLIN bibliographic data bases as well as to a number of RLG's CitaDel files. Document delivery was also available to the group, which included UNAM, the Universidad de Colima, the Universidad de Guadalajara, and seven other schools ("RLG to Serve," 1995).

\section{Future Relations}

\section{A. Rationale for Continued Interaction}

The cooperative endeavors just described do not occur in a vacuum but rather in the context of differing government structures, economies, educational systems, and cultural heritages. "U.S. foreign relations with Mexico are among its most important and complex. They are shaped by a mixture mutual interests, shared problems, growing interdependence, and differing national perceptions" ("Background Notes: Mexico," 1994, p. 6). For many years our two nations have cooperated in order to solve a number of border issues including immigration, drug trafficking, the environment, and many others (Background Notes: Mexico, 1994).

Where do libraries fit into this picture of binational collaboration? Milam (1939, p. 231) noted that "Libraries are . . . ideal agencies for international cooperation" because they and their patrons cannot help but benefit from the exchange of knowledge that results from working together. Because libraries are educational and cultural institutions dedicated to service, they can indeed be models for other groups seeking to establish ties with their counterparts across borders or oceans. Tocatlian (1975) reviewed the rationale for international cooperation, examined incentives for doing so, and described numerous international library and information networks. Tocatlian (1975) noted that "cooperation has long been an essential ingredient of library and information management, at both the national and international level" (p. 2).
As Section IV illustrates, there is a long history of interaction between and among libraries and librarians in the United States and Mexico. Although there have been a variety of collaborative efforts, the extent of actual direct cooperation or resource sharing has been somewhat limited, although on the increase. However, the possibilities for working in tandem are numerous and should continue to be explored.

In writing about the need for continued collaboration, Ladrón de Guevara (1990) wrote "in spite of efforts made by librarians, institutions, and other organizations that have made advances in library development in Latin America, grave problems still persist, and they need to be explored again in the search for solutions" (p. 231). Even in a highly developed country like the United States, there are library problems that can be solved through cooperative efforts with other countries.

\section{B. U.S.-Mexico Resource Sharing}

\section{How U.S. Libraries Can Help Mexico}

In the past half century, Mexico and other Latin American countries have developed a strong foundation of librarianship based on local efforts and assistance from abroad. In the late 1930s and early 1940s, Latin American colleagues expressed a need for help with articulating a vision of what a library should be and for developing the rules necessary for acquiring, classifying, and cataloging their collections (Milam, 1939). Rivera (1941) suggested that U.S. librarians work with Latin American libraries to help them organize and make accessible rich collections of history and literature, including manuscripts. In reference to the opportunity to train Latin Americans in library organization and administration and for us to learn more about their countries, (Rivera, 1941, p. 113) noted that there was "a unique opportunity for service and a continent ready to receive it."

Milam (1939) also reported on requests for (1) copies of our publications, (2) fellowships for study and work in the United States, (3) help with establishing library schools, and (4) a traveling exhibit of modern librarianship. Latin American librarians also asked for (1) assistance with international interlibrary loan, (2) the publication in Spanish of library publications, (3) lists of U.S. works of interest to foreign readers, and (4) the translation of important North American books into Spanish.

Interest in collaboration with the United States continues in the mid$1990 \mathrm{~s}$, and although a few of the previously mentioned needs of 50 years ago remain, new areas of concern have since surfaced. A survey of 32 public Mexican university libraries conducted by CONPAB in 1989 revealed a great desire to work with their counterparts in the United States. This group expressed an interest in (1) the exchange of publications; (2) training in the 
United States via internships or exchanges of staff; (3) short courses and workshops taught by American librarians; and (4) donations of equipment, software, and books (R. Forney, personal communication, August 23, 1995).

In conversations with Mexican colleagues, Cluff (1991) identified three broad areas in which the United States might work cooperatively to assist Mexican colleagues: personnel, collections, and equipment. Specific needs identified by Mexican librarians included, but were not limited to, (1) exchange of personnel, (2) scholarships for study in the United States, (3) training programs for middle managers and other staff, (4) cooperative continuing education programs, (5) exchange of publications, (6) donations of duplicates and other unwanted materials, (7) document delivery between the two countries, (8) gifts of software, (9) evaluations of computer systems, and (10) information to assist in purchasing equipment, especially computers, etc.

In a meeting with Mexican librarians on February 23, 1995, the author received very similar suggestions for ways in which the United States could be of assistance: (1) development of tutorials in the use of automated systems; (2) assistance with the transfer of electronic data between disparate automated systems; (3) help with the development of bilingual, standardized subject headings; (4) exchange of library school professors and students; (5) assistance in the acquisitions process for U.S. publications, especially speeding up the receipt of materials; (6) exchange of library science researchers needed to raise the level of research in Mexico; (7) training programs through distance education from the United States; and (8) helping Mexico develop its own library science distance education program.

In summary, Mexican libraries would most appreciate help with (1) training of library staff, (2) developing and better utilizing automated systems, (3) interlibrary loan and document delivery, and (4) collection development. Such areas are either not well developed or lack the funding to achieve minimal standards.

\section{How Mexican Libraries Can Help the United States}

Shepard (1968) correctly noted that "cooperation is a two-way street" (p. 705). In this author's experience, there is a sincere desire on the part of Mexican librarians to work with U.S. libraries, to reciprocate, to share their ideas and expertise. Milam (1939) listed several ways in which Latin American librarians could assist their U.S. colleagues: (1) assistance in securing books and periodicals more quickly and easily (still a problem in 1996); (2) provision of current, regular bibliographies of Latin American publications; (3) access to information on libraries and their collections; (4) help with interlibrary loan; (5) translation of important works into English; and (6) opportunities for librarians to study and conduct research.
Ruby (1985) pointed out that there is a great void in terms of information on Mexico in the United States and suggested that Mexican librarians could identify and recommend sources to fill that gap. She also noted that American librarians could do the same for Mexican colleagues. In a similar vein, Mexico could offer access to historical materials and local authors reflecting the philosophy of Northern Mexico (Quintanilla C., 1989), something of potential interest to scholars and laypersons alike. Our Mexican colleagues can also share their public relations and outreach experience as well as how to create an environment attractive to and comfortable for Hispanic patrons (Ruby, 1985).

Other ways in which Mexico can offer help to librarians in the United States are (1) access to and information about special collections; (2) partnerships in international research projects; (3) videos of popular and indigenous culture; (4) cultural and language education; (5) exchange of personnel, material, and information; and (6) Spanish courses (Cluff, 1991). Additional assistance could come in the form of (1) identification of and access to archival collections, many outside of libraries, to benefit researchers; (2) opportunities for and assistance with research sabbaticals in Mexico; (3) loans of unique materials such as government publications, theses, and statistical data; (4) cataloging of unique historical and literary collections for inclusion in our national data bases; and (5) expertise with indigenous Mexican languages (meeting with Mexican librarians, February 23, 1995).

\section{Obstacles to Further Cooperation}

While most librarians would agree that interinstitutional cooperation is a priority, it is often difficult to put into practice, and it becomes even more difficult and complicated when it involves two different political entities such as the United States and Mexico. In Section III,A,1, several barriers to cooperation within Mexico were delineated. Many of these obstacles also hinder or slow progress on the international front. White (1982) identified five categories of barriers to library cooperation: (1) economic, (2) technological, (3) bureaucratic, (4) geographic, and (5) personal. To these can be added (1) the language barrier; (2) differing standards, say for cataloging or data format; (3) distance and communication problems; (4) the political realities of international interaction; and (5) apathy. In short, it is no easy matter to carry out collaborative efforts in the international arena.

Another very large obstacle to U.S.-Mexico collaboration is the fact that many libraries in Mexico are much less well developed than their counterparts in the United States. As noted earlier, one must have something to share for cooperation to be fruitful and many libraries in Mexico are in position of having very little to offer in the way of collections and other resources. The reality is that in Mexico there are often extraordinary needs that can only 
be alleviated through cooperative efforts with other Mexican or American libraries. However, Mexican librarians can offer their U.S. colleagues expertise and the intellect to solve a variety of library problems. With a long tradition of "doing more with less," they are particularly adept at managing scarce resources, something American librarians could benefit from.

\section{Suggested Future Activities}

A number of librarians have suggested additional ways in which the United States and Mexico could work together. In speaking of future cooperation between Arizona and Sonora libraries, Milam and Salas (1990) listed several possibilities: (1) promotion of library services; (2) increased access to information through loans, gifts, and exchanges; (3) exchange of experience and knowledge though training courses, scholarships, internships, and consulting; (4) securing gifts of furnishings and equipment for libraries in need; (5) involvement of libraries in cultural projects to benefit Hispanic communities; (6) securing discounts for books and equipment; and (7) bilateral participation in professional associations.

In reference to public library cooperation, Ruby (1985) suggested (1) interlibrary loan agreements, (2) shared public services programs, (3) exchange of personnel, (4) visits to libraries, (5) interns, and (6) joint projects for providing children's services. Other possible programs were outlined by Gutierrez-Witt (1985): (1) joint conferences to improve communication, share information, and establish personal contacts; (2) exchange of state and local government publications, especially for border libraries; (3) exchange of duplicate materials, especially those having to do with border culture and life; (4) visits to libraries for the purposes of training and keeping current; (5) projects to document border information sources; and (6) preservation of local historical sources. She also emphasized the need for libraries in the interior of Mexico, those with more resources, to assist those in the outlying regions beyond the capital to develop their collections and personnel.

Ladrón de Guevara Cox (1990) recommended the formation of an international committee, with representatives from Latin America and the United States to identify areas for cooperative endeavors among Latin America libraries and with the United States. In addition to representatives from national library associations, she stressed the need for participation by SALALM and OAS. Among the areas of critical need are (1) teaching and training in library science, (2) library research to advance the profession and produce publications, and (3) the translation of papers on library science into English and Spanish.

Seal (1992b) underlined the importance of the involvement of professional organizations in U.S.-Mexico cooperation, noting that they can provide the appropriate framework and necessary resources for bilateral activity. He also recommended (1) more interlibrary loan between the two countries; (2) the creation of a list of and guide to special collections, especially those with a focus on border topics; (3) cooperative preservation efforts, especially for manuscripts and other unique materials; and (4) the exchange of personnel, for both short- and long-term visits (Seal, 1989).

Our Mexican colleagues have also suggested the following possibilities: (1) cooperative projects among special libraries; (2) the identification and documentation of archival collections in Mexico of interest to researchers in both countries; (3) work with scholars to determine how they conduct research in order to better organize collections; and (4) cooperative distance education efforts (meeting with Mexican librarians, February 23, 1995).

Financial support for cooperative activity must be borne by individuals, institutions, and consortia, or by foundations and government agencies. Although a number of possible sources exist to finance international library cooperation, one is particularly well suited for U.S.-Mexico collaboration, the so-called Fideicomiso para la Cultura Mexico/USA. The U.S.-Mexico Fund for Culture is an independent organization founded in September 1991, to foster cultural exchange between our two countries. A joint effort of the Rockefeller Foundation, the Mexican National Council for Culture and the Arts, and the Bancomer Foundation, the foundation provides financial support for binational projects in the performing arts, defined by the fund as dance, theater, and music; museums and visual arts; media arts; cultural studies; literary and cultural publications; and libraries.

Headquartered in Mexico City, the Fideicomiso para la Cultura Mexico/ USA began with an initial annual budget of 1 million U.S. dollars. To date it has supported exchange programs, cooperative cataloging, exhibitions of books, collaborative preservation, and other resource-sharing efforts. The union catalog of rare books, the Antigua Bibliografia Mexicana cited earlier in Section III,B,1, was also funded by this program.

\section{E. NAFTA and U.S.-Mexico Library Relations}

The potential impact of the North American Free Trade Agreement (NAFTA) on libraries and library cooperation has already been discussed at great length, but with no consensus on exactly what that impact will be. Altbach (1994) noted that unlike the European Community agreement, NAFTA has no cultural or educational provisions, "but closer economic ties will inevitably have cultural and educational implications" (p. 48). Indeed, such implications are already being seen in the area of higher education where government, foundations, and educational leaders are at work on possible cooperative strategies. At trinational conferences in Racine, Wisconsin, in 
1992, and Vancouver, British Columbia, in 1993, representatives of each group worked to devise ways to improve the quality of higher education and to make the region more competitive economically.

Trilateral collaboration in the form of strategic alliances among government, business, and education is seen by many as a way to solve common problems in administration, libraries, and computing. Library linkages have been cited as having great possibilities for cooperation, and the importance of exchanges has been stressed as a way to share expertise and personnel (Maza, 1993). Although such meetings and their results are technically separate from NAFTA, they cannot be totally separate issues. Altbach (1994) noted that "one of the main lessons is that focusing on commercial relations is not enough, and that mutual understanding is an important part of any constructive relationship" (p. 43). Libraries can play a key role in that process. Educational bridges must be built to "provide the needed understanding, knowledge, and skills required to deal with more intimate trade relations, and general sensitivity to the complex cultures of North America" (Altbach, 1994, p. 49).

Looking more specifically at libraries, the Tratado de Libre Comercio (TLC), as it is called in Mexico, could affect libraries in four areas: (1) publishing, (2) education, (3) business, and (4) copyright. Some believe that NAFTA will help libraries by increasing the flow of Mexican books to the United States and Canada through the gradual elimination of tariffs on paper, ink, and printing equipment ("Book Manufacturers," 1993). Deal (1992) noted that the production costs for books in Mexico could be reduced if NAFTA leads to reduced paper costs. Figueredo (1994) contrasted the book industry of the United States with that of Mexico and Latin America in an attempt to determine the possible impact of NAFTA on publishing. Because of several complex factors, he concluded that it is too early to tell how the trade agreement will affect the book industry and ultimately libraries who must acquire Spanish language materials for their clientele.

Because more and more colleges and universities are adding courses and degrees in international business, there is an increasing demand on libraries for information about Mexico in general and NAFTA in particular. Libraries must not only strengthen collections of print resources but also provide electronic access to meet the demand for data. Likewise, as more and more American companies show an interest in investing in Mexico, there will be an impact on business reference service with particular interest in "importexport, business start-up information, directory services queries, and labor cost data." Unfortunately, there are limited numbers of information sources available to answer these reference questions (Phillips, 1991).

Finally, because NAFTA has provisions for the protection of intellectual property, libraries will be called upon to provide information on copyright issues related to trade between Mexico and the United States. In particular,
NAFTA protects computer programs, databases, sound recordings, and motion pictures, as well as other types of intellectual property such as trademarks, patents, and integrated circuits. Its goal is to increase trade and reduce losses from piracy and counterfeiting (Donahue, 1994). Whatever the impact of the TLC, libraries in the United States and Mexico should work together to share information that will help it succeed.

\section{References}

Ainsworth, S. (1994). Mexican information resources in electronic format. In Bowker Annual, 39th Ed., pp. 75-90. R. R. Bowker, New Providence, NJ

Almada de Ascencio, M., and Pérez de Almada, S. (1991). Scholarly information and serials in Latin America: Shifting political sands. Serials Librarian 21, 69-85.

Altbach, P. G. (1994). NAFTA and higher education: The cultural and educational dimensions of trade. Change 26(4), 48-49.

Annual Report of the U.S.-Mexico Libraries Subcommittee, International Relations Committee, June 1992.

Annual Reports [ALA], 1923-1924. ALA Bulletin 18, 202-256.

Aranda, J., and Gleaves, E. S. (1981). The Master's Program in Library and Information Science of the University of Guanajuato: A new step for Mexico. Leads 23(2), 1-2,6.

Arista, S., and Yáñez, J. A. (1983). "La Cooperación: Alternativa de Solución a la Problemática Económica que Enfrentan las Bibliotecas." Paper presented at the XIV Jornadas de AMBAC, Zacatecas, Zacatecas, May 2-6, 1983.

Arión Castro, R. (1991). "Red bibliotecaria de los institutos Technológicos (REBIT) zona 3 Desarrollo y tecnología." Paper presented at the XXII Jornadas de AMBAC, Tuxtla Gutiérrez Chiapas, May 13-15, 1991 .

Arteaga Carlebach, G. (1990). ARDUSI: Primera red de bibliotecas en México. In Latin American Frontiers, Borders, and Hinterlands: Research Needs and Resources: Papers of the Tbirty-Tbird Annual Meeting (1988) of the Seminar on the Acquisition of Latin American Library Materials (P. Covington, ed.), pp. 257-262. University of New Mexico (SALALM Secretariat), Albuquerque, NM.

Ayala, M. S., ed. (1984). Proceedings of the First Binational Conference on Libraries in California and Baja California, January 13-14, 1984, Serra Cooperative Library System, San Diego, CA.

Baldwin, C. M. (1991). Arizona promotes international librarianship. Special Libraries 82, 203-204.

Bayardo Gómez, P. (1985). "Protocolos de Intercambio entre bibliotecas universitarias de la frontera norte de México." Paper presented at the Second Binational Conference on Libraries of the Californias, Calexico, California and Mexicali, Baja California, November 11-12, 1985

Benson, S. S. (1990). Pooling resources: The OAS programs for library and archives development in the 1980s. In Latin American Frontiers, Borders, and Hinterlands: Research Needs and Resources Papers of the Thirty-Third Annual Meeting (1988) of the Seminar on the Acquisition of Latin American Library Materials (P. Covington, ed.), pp. 245-256. University of New Mexico (SALALM Secretariat), Albuquerque, NM.

Bernal Flores, V., Castillo de Sáinz, T., Palacios de Avalos, M., and Reyes Ramos, G., eds. (1982). Cooperación Bibliotecaria: Estado Actual y Perspectivas. Memorias. IV Semana de Bibliotecología, September 29-October 4, 1980. Universidad Autónoma de Guadalajara, Dirección de Bibliotecas, Guadalajara, Jalisco.

La Bibliotecologia en el México Actual y Sus Tendencias. (1992). Dirección General de Bibliotecas, UNAM, México, D.F

Bixler, P. (1969). The Mexican Library. The Scarecrow Press, Inc., Metuchen, NJ. 
Bliss, N. J. (1995). International Librarianship. In Encyclopedia of Library and Information Science (A. Kent, ed.), Vol. 56 (Suppl. 19), pp. 214-233. Dekker, New York.

Book manufacturers hail NAFTA. (1993). Publisbers Weekly 240 (Nov. 22), 15.

Brief Board and Committee Reports [ALA]. ALA Bulletin 27, 450-473.

Brown, A. N. (1885). Note on the National Library of Mexico. Library fournal 10, 248-249.

Carrión, G. (1977). "Progress and Problems of Librarianship in Latin America with Emphasis on Mexico." Speech presented at the Graduate School of Library Science, The University of Texas at Austin, October 6, 1977.

Carrión Rodrígues, G. (1981). Mexico. In International Handbook of Contemporary Developments in Librarianship (M. M. Jackson, ed.), pp. 559-565. Greenwood Press, Westport, CT.

Carrión Rodríguez, G. (1992). Las Bibliotecas Especializadas en México. In La Bibliotecología en el México Actual y Sus Tendencias, pp. 59-72. Dirección General de Bibliotecas, UNAM, México, D.F.

Cluff, E. D. (1991). Libraries and librarians in Mexico. College \&o Research Libraries News 52, 370-371.

Coleman, M. P. (1934). In search of a Mexican library. Wilson Bulletin for Librarians 9, 13-16. Comisión de Relaciones Internacionales. (1992). Noticiero de la AMBAC No. 92,2.

Daniels, M. (1960). The promotion of libraries in the Americas: A five-year report of activities of the Organization of American States. Library Quarterly 30, 201-208.

Deal, C. W. (1987). The Latin American microform project: A model for cooperation. In Intellectual Migrations: Transcultural Contributions of European and Latin American Émigré: Proceedings of the 31 st Annual Meeting of the Seminars on the Acquisition of Latin American Library Materials (I. L. Sonntag, ed.), pp. 277-282. University of Wisconsin-Madison (SALALM Secretariat), Madison, WI.

Deal, C. W. (1992). Academic publishing in Mexico. ARL: A bimontbly newsletter of research library issues and actions May 1, 1992, No. 162, 3-4.

Dirección General de Bibliotecas, Secretaria de Educación Pública. (1991). La Red Nacional de Bibliotecas Públicas. Consejo Nacional para la Cultura y las Artes, Mex́ico, D.F.

Donahue, G. (1994). Intellectual property issues. In Latin America: The Emerging Information Power: 1993 State-of-the-Art Institute, pp. 1-5. Special Libraries Association, Washington, DC.

Enciso Carbajal, B., and Gallardo Gómez, H. (1984). "Cooperación e Información: bases de un sistema." Paper presented at the XV Jornadas de AMBAC, Tlaxcala, Tlaxcala, April 30May 4, 1984.

Estancias en el CUIB durante 1991. (1991). Investigación Bibliotecologica 5(11), 65-66.

Fernández, R. M. (1989). La crisis económica y los servicios bibliotecarios y de información en México. Investigación Bibliotecológica 3(7), 21-26.

Fernández de Zamora, R. M. (1976). Libraries in Mexico. In Encyclopedia of Library and Information Science (A. Kent, ed.), Vol. 18, pp. 1-40. Dekker, New York.

Fernández de Zamora, R. M. (1987). Cronoloǵia Bibliotecaria Mexicana 1900-1988. Investigación Bibliotecológica 1(3), 48-59.

Fernández de Zamora, R. M. (1988). "Reseña sobre los Programas de Cooperación en México." Paper presented at the Reunión de Trabajo sobre Cooperación Bibliotecaria, México, D.F. September 17-18, 1987.

Fernández de Zamora, R. M. (1990a). The economic crisis and the scientific, technical and cultural information services in Mexico. International Library Review 22, 263-271.

Fernández de Zamora, R. M. (1990b). Libraries in the Mexico City earthquake. Information Development 6, 140-143.

Fernández de Zamora, R. M. (1991). Library resources in Latin America: A general panorama. IFLA foumal 17, 45-54.
Fernández de Zamora, R. M. (1992). La Biblioteca Nacional de México y la bibliografia mexicana. In La Bibliotecología en el México Actual y Sus Tendencias, pp. 31-45. Dirección General de Bibliotecas, UNAM, México, D.F.

Fernández de Zamora, R. M., Ansoleaga de López, I., García Velarde, R., and Saavedra Fernández, O. (1977). "Posibilidades de Cooperación en México." Paper presented at the VIII Jornadas de AMBAC, Guadalajara, Jalisco, May 1-6, 1977.

Figueredo, D. (1994). The new NAFTA world: More books for your library? Wilson Library Bulletin 68(8), 32-33.

First International Library Fellows Announced. (1993). International Leads 7(4), 6-7.

Fitz, R. (1986). United States Information Agency Library and Book Programs. In Bowker Annual, 31 st ed., pp. 125-128. Bowker, New York.

Galvin, T. J. (1985). "Igualdad de Acceso a la Información: Una perspectiva transfronteriza." Paper presented at the Second Binational Conference on Libraries of the Californias, Calexico, California and Mexicali, Baja California, November 11-12, 1985.

García Moreno, C. E. (1980). Mexico. In ALA World Encyclopedia of Library and Information Services, pp. 369-370. American Library Association, Chicago.

Garduño, R. (1985) "Co-operation in Mexican University Libraries." Paper presented at the IFLA General Conference, Chicago, Illinois, August 1985.

Garmon, J. F. (1990). Texas Southmost serves college and community. Library fournal $115(3), 143$.

Goldman, M. K. (1978). Technical information services in Mexico. Special Libraries 69, 355-359. Greer, A. F. P. (1919). Library experiences in Mexico. Library foumal 44, 219-221.

Gregory, G. (1995). NAFTA spurs cooperation at trinational forum in Mexico City. American Libraries 26, 507-508.

Gutiérrez-Witt, L. (1985). "El Desarrollo de las Bibliotecas: El Area Fronteriza E.U.-México." Paper presented at the Second Binational Conference on Libraries of the Californias, Calexico, California and Mexicali, Baja California, November 11-12, 1985.

Hands across the border. (1986). Library Fournal 111, 23.

Hazen, D. C. (1995). "Preservation Priorities in Latin America." A report from the 60th IFLA General Conference, Havana, Cuba, August 1994.

Heliodoro Valle, R. (1923). Libraries in Mexico. Library Fournal 48, 265-268.

Hixson, I. (1956). Introduction. In Final Report of the Seminar on the Acquisition of Latin American Library Materials (Chinsegut Hill, Brooksville, Florida, June 14-15, 1956), pp. i-iv. University of Florida Libraries, Gainesville, FL.

Hoffert, B. (1993a). Crossing borders: U.S./Mexican forum tackles common concerns. Library fournal 118(12) $32-35$.

Hoffert, B. (1993b). Guadalajara primed for book buying. Library fournal 118(12) 34-35.

Kahl, S. C. (1993). A first step: The U.S.-Mexico interlibrary loan project. Fournal of Interlibrary Loan, Document Delivery \& Information Supply 4, 17-24.

Kinney, J. M. (1971). The Texas consortium to microfilm Mexican archival resources. College $b$ Research Libraries 32, 376-380.

Ladrón de Guevara Cox, H. (1990). Cooperation among libraries: A Mexican proposal. In Latin American Frontiers, Borders, and Hinterlands: Researcb Needs and Resources: Papers of the ThirtyTbird Annual Meeting (1988) of the Seminar on the Acquisition of Latin American Library Materials (P. Covington, ed.), pp. 231-234. University of New Mexico (SALALM Secretariat), Albuquerque, NM.

Latin American seminar on official publications makes recommendations. (1991). College of Researcb Libraries News 52, 583.

Lau, J. (1993). Mexican information policy: A scattered decision model. In Latin America: The Emerging Information Power: 1993 State-of-the-Art Institute, pp. 132-143. Special Libraries Association, Washington, DC. 
Lau, J. G. (1982). "EI Préstamo Interbibliotecario en México: Factores a Considerar." Paper presented at the XIII Jornadas de AMBAC, Hermosillo, Sonora, May 3-7, 1982.

Lau, J. G. (1983). "La Crisis Nos Obliga a Cooperar." Paper presented at the XIV Jornadas de AMBAC, Zacatecas, Zacatecas, May 2-6, 1983.

León Saavedra, C. (1983). "Cooperación Bibliotecaria." Paper presented at the XIV Jornadas de AMBAC, Zacatecas, Zacatecas, May 2-6, 1983.

Levinson, A., and Reynel Iglesias, H. (1993). The online industry in Mexico. Online 17(3), $116-119$

Litton, G., and Krzys, R. (1986). Latin American librarianship: A area study. In Encyclopedia of Library and Information Science (A. Kent, ed.), Vol. 40, pp. 114-272. Dekker, New York. Lorenz, J. G., et al. (1972). The Library of Congress abroad. Library Trends 20, 548-576.

Macías-Chapula, C. A. (1985). A descriptive study of ninety-two hospital libraries in Mexico. Bulletin of the Medical Library Association 83, 66-70.

Magaloni, A. M. (1993). The Mexican library revolution: Taking books to the people. Logos 4, 81-83.

Magaloni de Bustamante, A. M. (1992). Red Nacional de Bibliotecas Públicas: Desarrollo, Servicios y Resultados. In La Bibliotecología en el México Actual y Sus Tendencias, pp. 73-80. Dirección General de Bibliotecas, UNAM, México, D.F.

Magaloni de Bustamante, A. M. (1993). Mexico. In ALA World Encyclopedia of Library and Information Services, 3rd ed., pp. 570-572. American Library Association, Chicago.

Manrique de Lara, J. (1935). The popular library movement in Mexico. Wilson Bulletin for Librarians 9, 409-414.

Maza, E. (1993). Con base en el TLC, Canadá, Estados Unidos y México negocian ya la estandarización de su educación superior. Proceso September 6, 1993, No. 879, 6-9. Mexican, American librarians recommend cooperation. (1990). American Libraries 21, 1092.

Mexican library first in Latin America to use FirstSearch. (1995). OCLC Newusletter No. 216, $14-15$.

Milam, C. (1939). Some possibilities of library cooperation with Latin America. ALA Bulletin 33, 227-231.

Milam, C. H. (1944a). Notes on the visit to Latin America. ALA Bulletin 38, 299-300.

Milam, C. H. (1944b). Visit to Latin America. ALA Bulletin 38, 229-230.

Milam, S., and Salas, C. (1990). "Cooperación Bibliotecaria entre México y los Estados Unidos: La Experiencia Sonora-Arizona." Paper presented at the XXI Jornadas de AMBAC, México, D.F., May 2-4, 1990

Minutes of Meeting. U.S./Mexican Relations Committee, College and University Libraries Division, Texas Library Association, Houston, Texas, April 7, 1992.

Morales, E. (1987). Librarianship Research in Mexico. In Comparative and International Librarianship (P. S. Kawatra, ed.), pp. 171-178. Envoy Press, New York.

Morales Campos, E. (1976). Las Bibliotecas Universitarias en México. Bibliotecas y Arcbivos 7, 93-115.

Morales Campos, E. (1990). Breve descripción del sistema bibliotecario mexicano. Libros de México No. 18, 29-36.

Morales Campos, E. (1992). Ten years of library science research in Mexico. International fournal of Information and Library Research 4, 81-87.

Morales Campos, E. (1994). "U.S.-Mexico Interlibrary Loan." Paper presented at the 60th IFLA General Conference, Havana, Cuba, August 1994.

Morales Campos, E., and Ramírez Leyva, E., comp. (1992). Edición Conmemorativa del X Aniversario del Centro Universitario de Investigaciones Bibliotecológicas, 2 v., Consejo Nacional para la Cultura y las Artes, Dirección General de Bibliotecas, and Centro Universitario de Investigaciones Bibliotecológicas, México, D.F.
Mortenson Center for International Librarianship. (1993). International Leads 7(1), 6-8. Neugebauer, R. L. (1992). Second Transborder Library Forum is successful! Against the Grain 4(3), 14.

Orozco Tenorio, J. (1977). "Los Recursos Compartidos en las Bibliotecas Académicas." Paper presented at the VII Jornadas de AMBAC, Guadalajara, Jalisco, May 1-6, 1977.

Orozco Tenorio, J. (1988). Information crisis in Latin America. College \& Research Libraries News 49, 79-80.

Orozco Tenorio, J. (1992). La Cooperación Bibliotecaria en México. In La Bibliotecología en el México Actual y Sus Tendencias, pp. 267-275. Dirección General de Bibliotecas, UNAM, México, D.F.

Pan American Union. (1930). Books and Libraries in Mexico. Library and Bibliography Series, No. 3. Pan American Union, Washington, DC.

Pan American Union. (1962). The Inter-American Program of Library and Bibliograpbic Development of the Organization of American States: A Statement of Principles and Practice. General Secretariat, Organization of American States, Washington, DC.

Peñalosa, F. (1953). The development of libraries in Mexico. Library Quarterly 23, 115-125.

Pérez Monroy, I. C. (1991). "La Biblioteca Benjamín Franklin: Información especializada." Paper presented at the XXII Jornadas de AMBAC, Tuxtla Gutiérrez, Chiapas, May 13-15, 1991.

Phillips, R. F. (1991). Nine-state survey reveals interest in business with Mexico. Colorado Libraries 17(1), 26-27.

Las Primeras Jornadas Mexicanas de Biblioteconomía, Bibliografía y Canje. (1957). Boletín de la Asociación Mexicana de Bibliotecarios 1(1), 6-15.

Quijano Solís, A. (1982). Consideraciones sobre el Sistema OCLC en Bibliotecas Mexicanas. In Cooperación Bibliotecaria: Estado Actual y Perspectivas, pp. 127-137. Memorias. IV Semana de Bibliotecología, September 29-October 4, 1980. Universidad Autónoma de Guadalajara, Dirección de Bibliotecas, Guadalajara, Jalisco.

Quintanilla C. M. de J (1989). "Los servicios bibliotecarios en las zona fronteriza: MéxicoNorteamericana hacia una mejor comprensión entre vecinos." Paper presented at the $\mathrm{XX}$ Jornadas de AMBAC, Saltillo, Coahuila, May 2-4, 1989

Ramírez Escárcega, A. (1984). "Conclusions del Segundo Seminario de Cooperación en Bibliotecas y Centros de Información." Paper presented at the XV Jornadas de AMBAC, Tlaxcala, Tlaxcala, April 30-May 4, 1984.

Reunión de Trabajo sobre Cooperación Bibliotecaria. (1988). (Memoria, September 17-18, 1987, México, D.F.). Instituto Tecnológico Autónomo de México, México, D.F.

Rivera, R. O. (1941). Cooperation among the libraries of the western hemisphere. Inter-American Bibliographical Review 1, 112-117.

RLG to Serve Mexican Universities. (1995). Information Retrieval \& Library Automation 31(5), 7-8 Robles Zafra, A. (1983). "Consideraciones Básicas para la Cooperación Bibliotecaria." Paper presented at the Segundo Seminario de Cooperación en Bibliotecas y Centros de Información, Monterrey, Nuevo León, November 24-26, 1983.

Rodríguez Gallardo, A. (1977). Some Aspects of Mexican Library Development. In Bowker Annual, 22nd Ed., pp 423-428. Bowker, New York.

Rodríguez Gallardo, A. (1992). El Sistema Bibliotecario de la UNAM. In La Bibliotecologia en el México Actual y Sus Tendencias, pp. 15-30. Dirección General de Bibliotecas, UNAM, México, D.F.

Rojas, L. M. (1919). The National Library of Mexico. Library fournal 44, 216-218.

Ruby, C. (1985). "México y los Estados Unidos: Dos Naciones del Pacífico." Paper presented at the Second Binational Conference on Libraries of the Californias, Calexico, California and Mexicali, Baja California, November 11-12, 1985. 
Sáenz, V. J. (1983). "Proyecto de Cooperación entre Bibliotecas del Noreste de México." Paper presented at the XIV Jornadas de AMBAC, Zacatecas, Zacatecas, May 2-4, 1983.

Savary, J. (1975). Library Cooperation in Latin America. In Encyclopedia of Library and Information Science (A. Kent, ed.), Vol. 15, pp. 214-247. Dekker, New York.

Seal, R. A. (1989). "La cooperación entre bibliotecas académicas en la zona fronteriza." Paper presented at the XX Jornadas de AMBAC, Saltillo, Coahuila, May 2-4, 1989.

Seal, R. A. (1990a). El proyecto de prueba de préstamo interbibliotecario entre México y los Estados Unidos. Investigación Bibliotecológica 4(8), 29-30.

Seal, R. A. (1990b). "The U.S.-Mexico Interlibrary Loan Project." Paper presented at the Arizona Library Association, Phoenix, Arizona, November 16, 1990.

Seal, R. A. (1991). The U.S.-Mexico Interlibrary Loan Project. In Advances in Library Resource Sharing (J. Cargill and D. J. Graves, eds.), Vol. 2, pp. 165-175. Meckler Publishing, Westport, CT.

Seal, R. A. (1992a). Untitled talk presented at the Second Transborder Library Forum, Hermosillo, Sonora, Mexico, March 20, 1992

Seal, R. A. (1992b). "Cooperation between Libraries in the U.S. and Mexico." Paper presented at the Feria Internacional del Libro, Guadalajara, Mexico, November 29, 1992.

Seal, R. A. (1993). U.S.-Mexico Libraries Subcommittee (ALA/IRC). REFORMA Newsletter 12(3), 13.

Segundo Seminario de Cooperación en Bibliotecas y Centros de Información. (1983). (Memorias, November 24-26, 1983, Monterrey, Nuevo León). ABIESI, Monterrey, Nuevo León.

Seminario de Cooperación en Bibliotecas y Centros de Información. (1977). (Memorias, September 14-16, 1977, Saltillo, Coahuila). ABIESI, México, D.F.

Severance, H. O. (1938). Fields of library and bibliographical investigations open to American scholars in Latin America. Inter-American Bibliographical and Library Association Proceedings $1,175-182$.

Shaw, R. R. (1947). International activities of the American Library Association. ALA Bulletin 41, 199-232.

Sheldon, B. E. (1985). "Servicios Bibliotecarios en la Region Fronteriza Estados Unidos/ México-El Papel de Tres Instituciones claves: las Bibliotecas Estatales, las Asociaciones Profesionales, y los Programas de Educación Bibliotecológica." Paper presented at the Second Binational Conference on Libraries of the Californias, Calexico, California and Mexicali, Baja California, November 11-12, 1985.

Shepard, M. D. (1968). International dimensions of U.S. librarianship. ALA Bulletin 62, 699-710. Shepard, M.D. (1984). Information systems and library automation in Latin America. In Advances in Librarianship (W. Simonton, ed.), Vol. 13, pp. 151-184. Academic Press, Orlando, FL.

SLIS Faculty and Students at Escuela National de Biblioteconomía y Archivonomía. (1995). Call Number 53(2), 4

Sullivan, P. (1972). The international relations program of the American Library Association. Library Trends 20, 577-591.

Sussman, J. (1973). United States Information Service Libraries (University of Illinois Graduate School of Library Science, Occasional Papers, No. 111). University of Illinois, UrbanaChampaign, IL.

T. de Zubarán, J. (1956). "Préstamo Interbibliotecario y Servicio de Fotoduplicación." Paper presented at the [first] Jornadas de AMBAC, México, D.F., December 2-7, 1956

Tamez Solís, P. (1992). El Financiamiento de las Bibliotecas Universitarias Mexicanas. In $L$ Bibliotecologia en el México Actual y Sus Tendencias, pp. 229-255. Dirección General de Bibliotecas, UNAM, México, D.F.

Thigpen, W. K. (1969). Ben Franklin in Mexico. Wilson Library Bulletin 43, 452-455.
Thomas Giraud, S., and Barberena Blásquez, E. (1986). "Redes de Bibliotecas: Un ejemplo de metodología para su creación y operación." Paper presented at the XVII Jornadas de AMBAC, Puebla, Puebla, April 23-May 2, 1986.

Tocatlian, J. (1975). International information systems. In Advances in Librarianship (M. J. Voigt, ed.), Vol. 5, pp. 1-58. Academic Press, New York.

U.S. Department of State. Bureau of Public Affairs. Office of Public Communication. (1994) Background Notes: Mexico 4(4), Washington, D.C.

Verdugo Sánchez, J. A. (1992). Recomendaciones sobre el diplomado como educación no forma en el área bibliotecológia (Documento preliminar CNB). Investigación Bibliotecológica 6(12) $45-46$.

Verdugo Sánchez, J. A, and Fernández de Zamora, R. M., comp. (1990). Primer Seminario Nacional de Bibliotecarios Titulados de México: Bibliotecología, Información y Sociedad en México, Memorias (Oct. 9-10, 1989). Colegio Nacional de Bibliotecarios, A. C., Consejo Nacional de Ciencia y Tecnología, México, D.F.

Voutssás, J., Rodríguez, V., Ladrón de Guevara, H., Feria, L., and González Arteaga, M. (1989). Estudio sobre las estrategias planteadas a nivel nacional acercas de las redes de bibliotecas y su posible desarrollo. Universidad Nacional Autónoma de México (UNAM) and Asociación Nacional de Universidades e Institutos de Educación Superior (ANUIES), México, D.F.

White, C. M. (1969). Mexico's Library and Information Services: A Survey of Present Conditions and Needs. The Bedminster Press.

White, C. M. (1970). Acceleration of library development in developing countries. In Advances in Librarianship (M. J. Voigt, ed.), Vol. 1, pp. 241-285. Academic Press, New York.

White, T. (1982). La Cooperación Bibliotecaria y Como Optimizarla. In Cooperación Bibliotecaria: Estado Actual y Perspectivas, pp. 37-65. Memorias. IV Semana de Bibliotecología, Septembe 29-October 4, 1980. Universidad Autónoma de Guadalajara, Dirección de Bibliotecas, Guadalajara, Jalisco.

Wilson, J., and Shepard, M. D. (1977). Organization of American States. In Encyclopedia of Library and Information Science (A. Kent, ed.), Vol. 21, pp. 16-35. Dekker, New York. 